\title{
Malaysian Capital Controls: Macroeconomics and Institutions
}

Simon Johnson, Kalpana Kochhar, Todd Mitton, and Natalia Tamirisa 



\title{
IMF Working Paper
}

Research Department

\section{Malaysian Capital Controls: Macroeconomics and Institutions}

\author{
Prepared by Simon Johnson, Kalpana Kochhar, Todd Mitton, and Natalia Tamirisa ${ }^{1}$
}

February 2006

\begin{abstract}
This Working Paper should not be reported as representing the views of the IMF. The views expressed in this Working Paper are those of the author(s) and do not necessarily represent those of the IMF or IMF policy. Working Papers describe research in progress by the author(s) and are published to elicit comments and to further debate.

We analyze the capital controls imposed in Malaysia in September 1998. In macroeconomic terms, these controls neither yielded major benefits nor were costly. At the same time, the stock market interpreted the capital controls (and associated events) as favoring firms with stronger political connections, and some connected firms reportedly received advantages immediately following the crisis. Analysis of financial accounts indicates that connected firms outperformed unconnected firms before the 1997-98 crisis but not afterward. After the crisis, connected firms were either not supported as much as the market had expected or the benefits they received were not manifest in their published accounts.

JEL Classification Numbers: F21, F32, F40, G18, G30

Keywords: Malaysia, capital controls, Asian crisis, political connections, stock markets

Author(s) E-Mail Address: SJohnson@imf.org; KKochhar@imf.org;

Todd.Mitton@byu.edu; NTamirisa@imf.org

1 IMF, National Bureau of Economic Research (NBER), Center for Economic Policy Research and Massachusetts Institute of Technology; IMF; Brigham Young University; and IMF respectively. For helpful comments we thank Sebastian Edwards, Peter Henry, participants in the NBER pre-conference and conference on International Capital Flows, and colleagues at the IMF. Ioannis Tokatlidis provided outstanding assistance. All the information used in this paper is from publicly available sources. Corresponding author: Simon Johnson: sjohnson@imf.org.
\end{abstract}




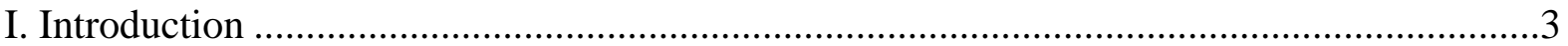

II. Brief Chronology of Capital Controls and Macroeconomic Policies ................................5

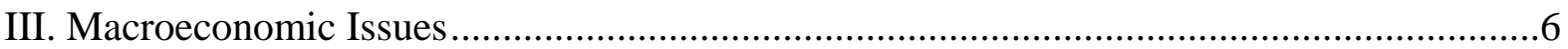

A. Understanding Motivation for Controls ........................................................6

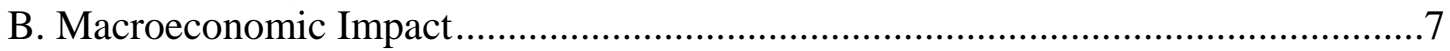

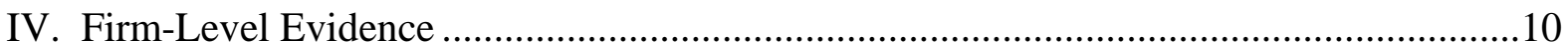

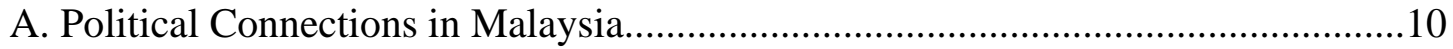

B. Identifying Firm-Level Political Connections....................................................10

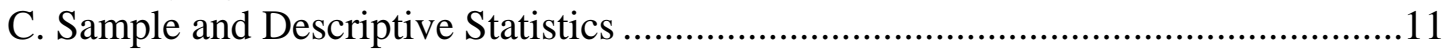

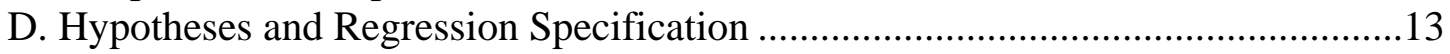

E. The Crisis Period: July 1997-August 1998_.........................................................14

F. Effects of Capital Controls: September 1998 .....................................................15

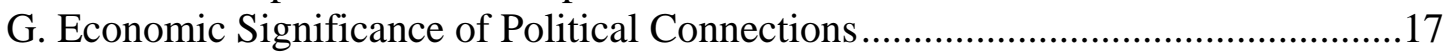

H. After Imposition of Capital Controls: 1999-2003 ..............................................18

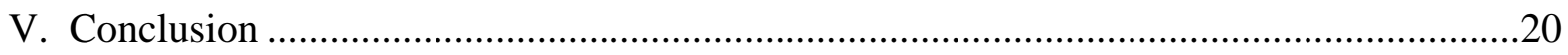

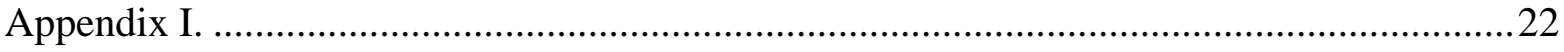

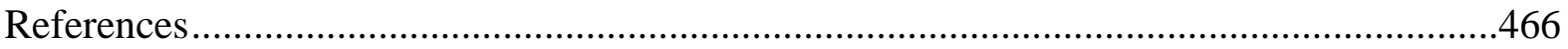

Figures

1. Malaysia: Cumulative and Net Portfolio Flows, 1997-2000....................................23

2. Malaysia: International Reserves and Exchange Rate, 1995-2002 .............................23

3. Malaysia and Thailand: Swap Differentials, May-December 1998 ...........................24

4. Selected Asian Countries: Monetary Indicators, 1998-2001 ....................................25

5. Selected Asian Countries: Real GDP Growth, 1996-2001 ......................................26

6. Selected Asian Countries: Political Risk Index, 1995-2002 .......................................27

7. Governance Indicators in Percentile Rankings, 1998 ............................................28

8. Asian Countries: Fiscal Indicators, 1995-2000 ..................................................29

9. Selected Asian Countries: Private Fixed Investment 1990-2004................................30

Tables

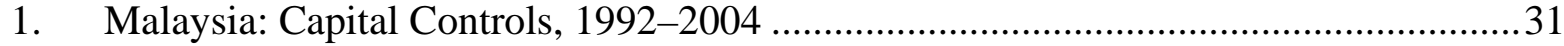

2. Summary Statistics of Firm-Level Sample ............................................................41

3. Political Connections and Crisis-Period Stock Returns ............................................42

4. Political Connections and Stock Returns Following Imposition of

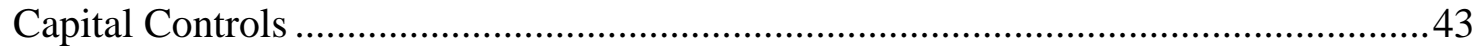

5. Political Connections and Median Operating Performance ....................................... 44

6. Political Connections and Operating Performance: Regression Analysis ....................45 


\section{INTRODUCTION}

Until the late 1970s, capital controls were widely used to prevent the free flow of funds between countries. A cautious relaxation of such controls during the 1980s proved consistent with greater economic integration among advanced countries and strengthened the case for capital market opening more generally. By the early 1990s, capital controls appeared to be finished as a serious policy tool for relatively open economies (Bhagwati, 1998a). Today, however, in the aftermath of the Asian crisis, the role of capital controls is being reconsidered.

In this reassessment of capital controls, recent experience in Malaysia-which reimposed capital controls in September 1998 - has been central to the two main views on capital controls. The more established view emphasizes macroeconomics. If a country faces a severe external crisis, particularly one caused by pure panic, and if orthodox macroeconomic policies have failed to restore confidence, Krugman (1998) argues that imposing capital controls may be an effective way to stabilize the economy. ${ }^{2}$ More generally, Bhagwati (1998a, 1998b) and Rodrik (2000) oppose the conventional wisdom that free capital flows help countries benefit from trade liberalization and argue instead that capital market liberalization invites speculative attacks. In this context, Malaysia's experience has been interpreted as demonstrating that capital controls can have positive macroeconomic effects (Kaplan and Rodrik, 2001), but this claim is controversial and was forcefully opposed by Dornbusch (2001). ${ }^{3}$

The second view of capital controls puts greater emphasis on institutions (i.e., the rules, practices, and organizations that govern an economy). Specifically, Rajan and Zingales (1998) argue that capital controls are an essential part of the package of policies that allows "relationship-based" capitalism to function. In this system, informal relationships between politicians and banks channel lending toward approved firms, and this is easier to sustain when a country is relatively isolated from international capital flows. If capital controls are relaxed, as in some parts of Asia in the early 1990s, the result may be overborrowing and financial collapse (Rajan and Zingales, 1998). ${ }^{4}$ In this context, Rajan and Zingales (2003) suggest that reimposing capital controls may be attractive if it enables politicians to support the financing of particular firms. If this view is correct, we should expect capital controls to be associated with more resources for favored firms. In the context of economic crises, there are two testable implications at the firm level. Firms with stronger political connections should (1) suffer more when a macroeconomic shock reduces the government's ability to

\footnotetext{
${ }^{2}$ Krugman was making policy recommendations for some Asian countries, including Malaysia.

${ }^{3}$ See also Perkins and Woo (1998 and 2000) and Hutchinson (2001).

${ }^{4}$ Theoretically, relaxing capital controls can lead to financial distress in at least three ways. First, local financial institutions respond by taking on more risk. Second, local firms borrow directly from international lenders who are either unable to assess risks appropriately or believe that there is an implicit sovereign guarantee. Third, after they lose their monopolies, local banks are less willing to bail out firms that encounter problems, as discussed in Petersen and Rajan (1995).
} 
provide advantages, and (2) benefit more when the imposition of capital controls allows a higher level of support for particular firms.

For the macroeconomic debate, the Malaysian experience is inconclusive. The capital controls worked in the sense that they were not circumvented on a large scale. They also never came under serious pressure, however, controls might have played a preventive rolethat is, to guard against risks to financial stability-but they were never tested in this role. At the same time, there is no convincing evidence of adverse macroeconomic consequences from the controls.

In contrast, the firm-level evidence lends support to the Rajan and Zingales view of capital controls. Our estimates indicate that in the initial phase of the crisis, from July 1997 to August 1998, roughly 9 percent of the estimated $\$ 60$ billion loss in market value for politically connected firms may be attributed to the fall in the expected value of their connections. With the imposition of capital controls in September 1998, up to 32 percent of the estimated \$5 billion gain in market value for firms connected to the prime minister may be attributed to the increase in the value of their connections. For connected firms, the value of political connections was in the range of 12-23 percent of their total market value at the end of September 1998.

The paper closest to our firm-level analysis is Fisman (2001), who estimates the value of political connections in Indonesia by looking at how stock prices moved when former president Suharto's health was reported to change. Fisman measures the direct effect of health shocks to a dictator, which is presumably quite specific to authoritarian systems, during a period of relative economic stability. The Malaysian experience lets us examine the interaction of connections and capital controls in a democracy. In addition, we are able to use variation between firms connected to politicians that continue in power and those that lose out. This helps ensure that political connections, rather than some other unobservable characteristics of firms, drive our results.

Our paper is part of a growing literature that examines the performance of relatively privileged firms. La Porta, Lopez-de-Silanes, and Zamarippa (2003) show that wellconnected Mexican banks engaged in a considerable amount of irresponsible lending before the 1995 crisis, and this presumably contributed to the severity of the crisis when it came. To our knowledge, no previous papers have tried to measure the combined effects of connections and capital controls.

Our work is also related to the recent literature that shows important links between institutions, firm-level governance, and macroeconomic outcomes. Johnson, and others (2000) present evidence that the Asian financial crisis had more severe effects in countries with weaker institutions in general and weaker investor protection in particular (as measured by La Porta, Lopez-de-Silanes, Shleifer, and Vishny, 1997, 1998). Mitton (2002) finds firmlevel evidence that weaker corporate governance was associated with worse stock price performance in the Asian crisis, and Lemmon and Lins (2003) confirm these results using different definitions of governance and outcomes. More broadly, Morck, Yeung, and Yu 
(2000) argue that in countries with weak property rights protection, stock price movements are predominantly driven by political shocks.

The paper is organized as follows. Section II summarizes the history of Malaysian capital controls. Section III reviews the macroeconomic evidence. Section IV assesses the firmlevel evidence. Section V concludes.

\section{Brief Chronology of Capital Controls And Macroeconomic Policies ${ }^{5}$}

In 1968 Malaysia removed restrictions on payments and transfers for current international transactions, accepting the obligations of the IMF's Article VIII. Exchange and capital account regulations were relaxed further in 1973, and Malaysia moved from a fixed to a floating exchange rate. Subsequently the authorities gradually liberalized capital controls, particularly in 1986-87. ${ }^{6}$

Table 1 reports the details of Malaysian capital controls since 1992. At the time of the Asian crisis, portfolio flows were generally free of restrictions. Domestic and international credit transactions in foreign currency were carefully controlled, but international trade and financial transactions denominated in ringgit were allowed and perhaps even promoted. As a result, an active and largely unregulated offshore market in ringgit developed.

After Thailand devalued in July 1997, the Malaysian ringgit came under severe pressure. Portfolio outflows intensified (Figure 1) and foreign exchange reserves plummeted (Figure 2). As currency traders took speculative positions against the ringgit in the offshore market, offshore ringgit interest rates rose markedly relative to onshore rates (Figure 3). This further intensified the movement of ringgit funds offshore.

The initial response of the authorities was to tighten macroeconomic policies. ${ }^{7}$ Spending cuts were introduced in 1997, and the 1998 budget was drafted to target a surplus of $2 \frac{1}{2} 2$ percent of GDP. Base lending rates were allowed to rise somewhat in response to higher interbank interest rates (Figure 4), and lending targets were adjusted to reduce growth of credit for financing purchases of real estate and securities. These measures had little stabilizing impact

\footnotetext{
${ }^{5}$ Sections II and III draw on publicly available data and documents, in particular, press releases, exchange notices, and annual reports of Bank Negara Malaysia (available at www.bnm.gov.my) as well as the IMF's Annual Report on Exchange Arrangements and Exchange Restrictions. For more details on the chronology of crisis in Malaysia and the authorities' response, see Meesook and others (2001) and Tamirisa (2004).

${ }^{6}$ In 1994, Malaysia temporarily reintroduced some controls to stem inflows of short-term capital.

${ }^{7}$ The Malaysian authorities intervened heavily in the foreign exchange market and sharply raised interest rates in July 1997. These measures were abandoned after a few days. In August 1997, the authorities introduced limits on ringgit swap transactions with nonresidents to stabilize the offshore market. They also restricted trading in blue chip stocks on the Kuala Lumpur stock exchange. For more details, see Meesook and others (2001).
} 
on financial markets as crisis continued to spread in the region. When the extent of the output collapse became clearer, by early 1998, fiscal policy became more expansionary. The target for the 1998 budget was relaxed to a surplus of $1 / 2$ percent of GDP in March 1998. A package of measures to strengthen the financial sector was also introduced at the same time.

In early September 1998, arguing that the measures and reforms that had been put in place by all countries affected by the Asian crisis did not appear to be returning stability to financial markets, the Malaysian authorities imposed capital controls and pegged the ringgit to the U.S. dollar. ${ }^{8}$ To close the offshore market in ringgit and ringgit assets, investors were required to repatriate all ringgit held offshore back to Malaysia, licensed offshore banks were prohibited from trading in ringgit assets, and residents were prohibited from granting or receiving ringgit credit vis-à-vis nonresidents. Among supporting measures, the authorities prohibited offshore trading of ringgit assets and brought to a halt long-standing trading in Malaysian shares in Singapore. ${ }^{9}$ In addition to controls on international transactions in the ringgit, the authorities imposed controls on portfolio outflows, particularly a one-year holding period on nonresidents' repatriating proceeds from the sale of Malaysian securities and a prior approval requirement-above a certain limit—for residents to transfer capital abroad.

The controls were carefully designed to withstand pressure-i.e., to close all known channels and loopholes for the supply of the ringgit to the offshore market and major portfolio outflows-while attempting not to affect foreign direct investment and current account convertibility (see Table 1). The authorities also stressed the temporary nature of controls. Furthermore, a number of pre-conditions facilitated the implementation of capital controlsa history of using some controls, effective state capacity, and generally strong bank supervision and regulation (Meesook and others, 2001; Latifah, 2002).

\section{MACROECONOMIC IsSUES}

\section{A. Understanding Motivation for Controls}

The authorities emphasized financial stability as the primary motivation for these controls. The official press releases that accompanied the introduction of capital controls underscored the following objectives: "(i) to limit the contagion effects of external developments on the Malaysian economy; (ii) to preserve the recent gains made in terms of the policy measures to stabilize the domestic economy; and (iii) to ensure stability in domestic prices and the ringgit

\footnotetext{
${ }^{8}$ See Table 1 and Bank Negara Malaysia, Press Release: Measures to Regain Monetary Independence, September 1, 1998, available at www.bnm.gov.my.

${ }^{9}$ The controls were gradually relaxed, beginning in December 1998. See Table 1 for more details.
} 
exchange rate and create an environment that is conducive for a revival in investor and consumer confidence and facilitate economic recovery."10

Although interpreting data in real time is more difficult than it is ex-post, it is now clear that the risks to financial stability in Asia had diminished by the summer of 1998. A significant portion of capital had already flowed out by the time the controls were imposed (Figure 1). The ringgit had already depreciated by 70 percent and pressure on the currency was letting up by the summer of 1998 (Figure 2). Offshore swap differentials for Malaysia (as for Thailand)—-were trending down (Figure 3). And, quarterly GDP growth data showed that the crisis had bottomed out in the first quarter of 1998 (Figure 5).

The Malaysian authorities acknowledged that the political and social fallout from the crisis in other countries did weigh on their decision to impose controls (Latifah, 2002). The authorities were concerned about the political and social stability "which defined the country even more than the deterioration in the level of wealth.” These concerns were consistent with a worsening of political risk indicators during summer 1998 (Figure 6, where a lower score indicates higher perceived risk), particularly following the political turmoil in Indonesia. Theoretically, in September 1998 there was a worst-case scenario of domestic capital flight and increased offshore speculation against the ringgit that would have entailed significant economic and political costs for the country. Seen in this light, the controls played a role in guarding against the eventuality of this scenario.

The worst case scenario did not come to pass in September $1998 .^{11}$ To a large extent, this reflected increased incentives for holding the ringgit, given the improvement in market sentiment about the region as signs of an economic turnaround became clearer, and also the increase in global liquidity following cuts in U.S. interest rates. Several observers have also noted that the ex post undervaluation of the ringgit made avoiding the capital controls unappealing (see, for example, IMF, 1999; Meesook and others, 2001; World Bank, 2000; and Jeong and Mazier, 2003). ${ }^{12}$

\section{B. Macroeconomic Impact}

Kaplan and Rodrik (2001) argue that the capital controls enabled a faster and less painful recovery in Malaysia compared with the experience in the Republic of Korea and Thailand. But their argument is based on the assumption that Malaysia in September 1998 should be

\footnotetext{
${ }^{10}$ See Bank Negara Malaysia Press Release: “Measures to Regain Monetary Independence,” September 1,1998, available at www.bnm.gov.my. The authorities considered the capital controls as complementing the introduction of the peg, which in turn was seen as an appropriate "strategic response to the unique circumstances at the time" and a way "to introduce a large degree of stability and predictability to mitigate the impact of market volatility on the real economy" (Latifah, 2002).

${ }^{11}$ Malaysia has turned out to be the only Asian-crisis country that did not have a government change during 1997-98.

${ }^{12}$ Capital controls and other measures aimed to close the offshore market prompted an influx of ringgit funds into the stock market, causing it to rally.
} 
compared with other countries when they adopted IMF programs (6-12 months earlier). It is hard to make this position persuasive.

Independent of capital controls, Malaysia was well placed to experience a shallower downturn and a faster recovery than other countries. As emphasized by Dornbusch (2001), initial conditions, particularly the "burden" of short-term corporate debt, were more favorable in Malaysia than in other Asian crisis countries. ${ }^{13}$ In terms of institutional indicators, Malaysia also stands out among its regional peers, with higher rankings of government effectiveness, regulatory quality, rule of law, and control of corruption (Figure 7).

In the event, the timing and magnitude of the output decline was similar in the four countries most seriously affected by the Asia-wide crisis (Indonesia, the Republic of Korea, Malaysia, and Thailand, hereinafter referred to as crisis countries). Hutchison's (2001) empirical assessment leads to a similar conclusion. Hutchison also points out that Kaplan and Rodrik's analysis does not take into account the fact that the Malaysian currency crisis perhaps would not have lasted until September 1998 if an IMF program had been in place from 1997.

Likewise, the timing and strength of the recovery of the Malaysian economy were similar to that of the other Asian crisis countries. By the summer of 1998, all the crisis affected countries had begun to show a recovery (Figure 5), and Malaysia recovered at about the same rate as the Republic of Korea and Thailand (the momentum of the recovery in Indonesia was weaker than in the other countries). There is thus no evidence so suggest that the Malaysian economy performed better than the others following the imposition of the controls. This is not surprising, given that Malaysia's macroeconomic policies were broadly similar to those in other crisis countries.

Some commentators argued that the controls could be used to allow the government to undertake expansionary fiscal and monetary policy without fear of worsening external imbalances (e.g., Perkins and Woo, 1998). However, the evidence shows that the Malaysian authorities did not use controls to pursue heterodox policies such as a substantial lowering of interest rates or providing a particularly aggressive fiscal stimulus. In the event, the timing and pace of interest rate reductions in Malaysia was not out of line with those in the other crisis countries where there were no capital controls (Figure 4). A comparison with the Republic of Korea is particularly instructive in this context. In nominal terms, interest rates in the Republic of Korea and Malaysia were similar during the period in question. But in real

\footnotetext{
${ }^{13}$ Malaysia has had a long-standing policy of controlling external borrowing by the domestic private sector. Besides prudential controls on external borrowing by banks and their domestic lending in foreign currency, external borrowing by domestic corporations above a certain limit required approval, which reportedly was given for projects that generated or saved foreign currency. The authorities see this measure as helping promote "natural hedging" of private debt service payments, whereby residents borrowing externally could meet their external (non-ringgit) obligations through their own foreign currency earnings (Latifah, 2002).
} 
terms, interest rates were brought down earlier and more aggressively in Korea: by the summer of 1998, they were already below those in Malaysia, and remained below after the controls were imposed. Moreover, the fiscal impulse provided in Malaysia was smaller than in other crisis countries in 1998 and broadly similar in 1999 (Figure 8 and Meesook and others, 2001). ${ }^{14}$ The current account surplus and increases in reserves during the recovery stage were larger in Malaysia than in other countries, in part reflecting the undervaluation of the ringgit. Throughout the crisis and into the capital control period the authorities pursued what are generally considered to be orthodox macroeconomic and structural policies.

All in all, there is no evidence in the data to suggest that capital controls made a visible difference in Malaysia's recovery process. Responsible macroeconomic policies and commitment to financial and corporate sector reforms, ${ }^{15}$ together with strong initial conditions and institutional capacity, should receive the main credit for the recovery in Malaysia. As experience in other crisis countries shows, these policies were possible without capital controls.

At the same time, there is no evidence that controls had lasting costs through affecting Malaysia's access to international portfolio capital. While Thailand, the Republic of Korea, and Indonesia also suffered lower investor ratings after the crisis hit, Malaysia suffered a particularly steep fall from 1998 to 1999. But by 2003, all four countries had regained their previous relative rankings. Three of the countries had slightly lower absolute rankings than before-only Indonesia was much lower. Malaysia's spreads widened by more than those of other countries after capital controls were introduced, but these effects unwound relatively rapidly.

One open question is whether there is any evidence that, after the capital controls, investors perceived Malaysia as a less desirable destination for foreign direct investment (FDI). According to the latest United Nations Conference on Trade and Development (UNCTAD) annual report on FDI, Malaysia has maintained a steady ranking (around $33^{\text {rd }}-34^{\text {th }}$ in the world) in terms of FDI "potential" (measured on the basis of "structural factors" such as physical infrastructure, GDP per capita, total exports and imports of natural resources, education, energy use, and the stock of FDI), but in terms of capital attracted it has slipped from around $5^{\text {th }}-10^{\text {th }}$ in the world before the crisis to $70^{\text {th }}-75^{\text {th }}$ after the crisis. Other Asian countries affected by the crisis - with the exception of Indonesia-did not experience similarly sharp falls in actual inward FDI performance, as assessed by UNCTAD.

In addition, the recovery in Malaysia's private fixed investment has been slower than in other crisis countries (Figure 9). The decline from high pre-crisis levels is consistent with the view that these countries were investing too much in the early and mid-1990s. While we do not yet have enough data to draw definite conclusions, it is striking that the Republic of Korea,

\footnotetext{
${ }^{14}$ The fiscal impulse was larger in 2000, but by this time controls had been significantly relaxed.

${ }^{15}$ See Lindgren and others (1999), Meesook and others (2001) and Latifah (2002) for a detailed discussion of structural reforms in Malaysia during and after the crisis.
} 
Thailand, and Indonesia have all shown a stronger recovery in private investment than has Malaysia. Private investment, as a percent of GDP, has recently been remarkably low-under 10 percent—in Malaysia, and only about half the regional average.

\section{FIRM-LEVEL EVIDENCE ${ }^{16}$}

\section{A. Political Connections in Malaysia}

Gomez and Jomo (1997) suggest there were two forms of political connections in Malaysia prior to 1997. The first is the official status awarded to firms that are run by ethnic Malays. The second consists of much more informal ties that exist between leading politicians and firms that are run by both Malay and Chinese business people.

Although ethnic Malays (known as Bumiputras, literally "sons of the soil”) account for some 60 percent of the population, business in Malaysia has historically been dominated by ethnic Chinese. With an eye toward correcting this imbalance, and partly in response to ethnic rioting in 1969, the government instituted the New Economic Policy (NEP) in 1970. Since that time, Bumiputras have been given, among other privileges, priority for government contracts, increased access to capital, opportunities to buy assets that are privatized, and other subsidies. The ruling coalition in Malaysia for over three decades has been the Barisan Nasional, which is dominated by the United Malays’ National Organisation (UMNO). Dr. Mahathir Mohammad, president of UMNO and Prime Minister of Malaysia from 1981 to 2003, consistently promoted Bumiputra capitalism (Gomez and Jomo, 1997).

The increased state intervention required for implementation of the NEP opened the door to greater political involvement in the financing of firms in Malaysia. During the 1990s, two government officials were most influential in promoting firms in Malaysia. The first was the prime minister. The second was Anwar Ibrahim, finance minister during the Asian crisis. ${ }^{17}$ Below we denote the first type of firm as PMC (prime minister connected) and the second type as FMC (finance minister connected).

\section{B. Identifying Firm-Level Political Connections}

To identify which firms have political connections with government officials, we rely on the analysis of Gomez and Jomo (1997). The analysis of Gomez and Jomo (1997) has been used

\footnotetext{
${ }^{16}$ This section draws on Johnson and Mitton (2003).

${ }^{17}$ Before moving on to the coding of political connections, it is important to note that there is no evidence suggesting that any unobserved characteristics of these firms determined their political affiliations. Before the Asian financial crisis, the evidence suggests that affiliations to either the finance minister or prime minister were close substitutes. Indeed, there is no evidence that the alliances between firms and specific politicians were the result of anything other than chance personal relationships (Gomez and Jomo, 1997, p. 126, p. 148-49). Any systematic differences in the performance of these firms should therefore be due to the changing relative value of their political connections.
} 
extensively to identify political connections in Malaysia in previous work including Johnson and Mitton (2003); Faccio (2005); Faccio, Masulis, and McConnell (2005); and Chong, Liu, and Tan (2005).

Using the analysis of Gomez and Jomo (1997) to identify connections suffers from some limitations. First, these authors do not claim to have exhaustively identified every firm with political connections in Malaysia. Second, although all connections identified by Gomez and Jomo (1997) are from before the Asian crisis, some are identified from earlier in the 1990s, creating the possibility that a connection could have disappeared prior to the beginning of the crisis. ${ }^{18}$ However, given the relative stability of the government over this period, it seems unlikely that changes in political connections would be prevalent during this period. Many political connections identified by Gomez and Jomo (1997) are unofficial and have not been verified by other sources. Finally, the coding of political connections does not measure the strength of these connections. Nevertheless, Gomez and Jomo (1997) offer an extensive analysis, and we take a systematic approach to identifying connections based on their work. Consequently, our coding of connections likely presents a fairly clear picture of investors' perceptions of political connections during this time period. See Appendix I for more details and examples of our coding.

\section{Sample and Descriptive Statistics}

Our sample is taken from the set of Malaysian firms in the Worldscope database. Worldscope maintains data on active and inactive firms, so there is no sample selection bias due to firms dropping out of the data set. The firms in our sample are representative of the firms listed on the main board of the Kuala Lumpur Stock Exchange. Firms not included in our sample include smaller unlisted Malaysian firms and multinationals with no local listing.

Table 2 reports the basic descriptive data for these firms. In this table we compare the performance of politically connected firms relative to unconnected firms prior to the crisis. We define political connections for each firm in our sample as outlined in the previous section. Table 2 also compares the performance of PMC firms to FMC firms, and shows the performance of non-financial firms separately. Row 1 reports the number of firms in each category of our sample; the total number of firms with available pre-crisis data is 424, of which 67 had identifiable political connections.

Row 2 of Table 2 shows that politically connected firms had significantly worse returns (compared with unconnected firms) during the crisis period of July 1997 to August 1998, although there was no significant difference between PMC and FMC firms. Row 3 shows that politically connected firms had significantly better returns (compared with unconnected

\footnotetext{
${ }^{18}$ In the second edition of their book, which was prepared in late 1997 and which appeared in 1998, Gomez and Jomo (1998) updated their list of political connections. We have used this revised list as a robustness check and find that it does not affect any of our main results. We prefer to use their precrisis list, however, as this was complete before there was any sign of economic trouble.
} 
firms) after the imposition of capital controls in September 1998, and that PMC firms performed much better than FMC firms during this period. Row 4 shows no significant differences between politically connected and unconnected firms in returns after September 1998.

Row 5 of Table 2 shows that, in terms of total assets, politically connected firms were significantly larger (about twice the size on average) compared with unconnected firms, although asset growth immediately before the crisis was not significantly greater in connected firms (Row 6). There is no evidence that PMC firms had larger size on average than FMC firms.

Row 7 of Table 2 suggests that politically connected firms were less profitable than unconnected firms (in terms of return on assets) before the crisis. ${ }^{19}$ However, in regression analysis (not reported here but available on request) we control for other firm characteristics such as firm size and industry, and find no evidence that politically connected firms had lower profitability before the crisis (Johnson and Mitton, 2003). ${ }^{20}$ Rows 8 and 9 show no differences in the liquidity (current ratio), and efficiency (asset turnover ratio), respectively, across the dimensions of political connections (in terms of t-tests of the means). The book-tomarket ratio is one way to examine whether investors perceive that there is expropriation of assets by managers or controlling shareholders. Row 10 shows that these ratios are not significantly different for any group of firms before the crisis.

In the next section of Table 2 we examine the financial leverage of firms prior to the crisis period. If politically connected firms had greater leverage prior to the crisis, then this could explain some or all of the performance differences in stock-price performance. A firm with higher debt would naturally be expected to perform worse in a crisis (compared to a firm with less debt) both because of the effect of leverage on a firm's covariation with the market and also because the depreciation of the local currency hurts a firm if any of its debt is denominated in foreign currency. In addition, if the government responds to the crisis by raising interest rates - as in Malaysia early in the crisis - this raises the cost of servicing corporate debt. The data on leverage in Table 2 show that firms with political connections had debt-asset ratios more than 11 percentage points higher, on average, than unconnected firms prior to the crisis (Row 11). In addition, leverage was rising significantly faster for connected firms prior to the crisis (Row 12). However, politically connected firms had less short-term debt (maturity less than one year) as a percentage of total debt (Row 13), and connected firms had a lower percentage increase in short-term debt prior to the crisis (Row 14). These apparent differences in leverage between connected and unconnected firms are only rough measures, of course, in that they do not account for differences in industry or other firm characteristics.

\footnotetext{
${ }^{19}$ This is consistent with the notion that politically connected firms were not well run, at least with respect to performance reported in audited statements (as opposed to private benefits).

${ }^{20}$ Using data through 1995, fewer firms, and a different specification, Samad, undated, finds that politically connected firms have higher profitability but no difference in investment behavior.
} 
In further regression analysis (not reported here but available on request) we control for other factors, and we still find that politically connected firms had more debt before the crisis (see Johnson and Mitton, 2003). Controlling for standard determinants of leverage—size, profitability, growth, and industry-accounts for some, but not all, of the difference in leverage between favored and other firms. ${ }^{21}$ After controlling for all these factors, among non-financial firms politically connected firms still had debt ratios five percentage points higher (with the coefficient significant at the 10 percent level).

Overall, the evidence in Table 2 does not suggest that favored firms performed differently during the crisis primarily because they were operated any better or worse (than unconnected firms) before the crisis. However, size and leverage stand out as the primary characteristics that differ between connected and unconnected firms, and we will control for these characteristics in subsequent regression analysis.

\section{Hypotheses and Regression Specification}

We now turn analysis of firm-level performance of connected firms relative to unconnected firms during the crisis period and imposition of capital controls. Note that the nature of the data do not let us distinguish the market perception of the capital controls separately from other events that took place at the same time and were associated with the imposition of these controls.

If political connections mattered in Malaysia, then the Rajan and Zingales view suggests three specific hypotheses:

- $\quad$ The stock price of politically connected firms should have fallen more in the early crisis period.

- When capital controls were imposed, the stock price of politically connected firms should have risen (relative to unconnected firms). Within the set of politically connected firms, the benefits of capital controls should be concentrated in PMC firms rather than FMC firms in September 1998.

- $\quad$ After the imposition of capital controls, PMC firms should have shown some evidence of having received advantages.

We examine the evidence for each of these hypotheses in turn. We begin by assessing the impact of political connections on stock price performance during the crisis period and after

\footnotetext{
${ }^{21}$ Specifically, larger firms had higher debt ratios, as predicted by Titman and Wessels (1988), moreprofitable firms had lower debt ratios, as would be suggested by Myers (1977), and firms with higher growth had higher debt ratios.
} 
the imposition of capital controls. Because we use monthly stock return data, we define the “crisis period” as July 1997 through August 1998. ${ }^{22}$

Other studies have focused on September 1998 as a key date in the Malaysian crisis. ${ }^{23}$ The most detailed account of Malaysia's economic crisis, Jomo (2001, Ch. 7), also identifies the beginning of September 1998 as the critical turning point. Returns for the month of September 1998 are used to assess the stock price impact of capital controls.

To study stock price performance, we estimate the following cross-sectional return model:

$$
\text { Stock return }_{i}=\alpha+\text { Political connection }_{i}+\text { Size }_{i}+\text { Leverage }_{i}+\text { Industry }_{i}+\varepsilon_{i} \text {, }
$$

where the stock return for firm $i$ is measured over a specified period. Stock returns are dividend-inclusive and expressed in ringgit. ${ }^{24}$ The political connection variables change according to the specification. Equation (1) also shows that we control for other factors that may influence returns; in particular, we control for those factors for which differences were demonstrated between connected and unconnected firms in Table 2. Size ${ }_{i}$ and Leverage $_{i}$ for each firm $i$ are as defined in Table 2, and Industry $y_{i}$ corresponds to a set of dummy variables corresponding to the primary industry of firm $i$, where industries are defined broadly, as in Campbell (1996).

\section{E. The Crisis Period: July 1997-August 1998}

Table 3 presents the results from these regressions for the period from July 1997 to August 1998. In the first three columns, the politically connected dummy variable is included. For nonfinancial firms, the coefficient on the politically connected dummy is -0.075, indicating that a political connection is associated with a greater stock price decline of 7.5 percentage points, on average, during the crisis period of July 1997 through August $1998 .^{25}$ For financial firms, the coefficient is similar, at -0.077 . These coefficients are significant at the 1 percent level of confidence. The control variables for size and leverage are also significant in these regressions, with larger size being associated with higher returns during the crisis, and higher leverage with lower returns.

\footnotetext{
${ }^{22}$ The beginning of the crisis period corresponds to the devaluation of the Thai baht on July 2, 1997, a date generally considered to be the starting point of the Asian financial crisis. The end of the crisis period and start of the "rebound period" corresponds to the imposition of capital controls on September 2, 1998 when the stock index began a sustained upward trend.

${ }^{23}$ Capital controls were announced on September 1 and the ringgit-dollar rate was fixed in the early afternoon of September 2, 1998.

${ }^{24}$ We do not calculate abnormal returns using historical betas because data limitations prevent calculation of pre-crisis betas for many of the firms in the sample. Even requiring a price history of just 24 months, we can calculate betas for only 65 percent of the firms in our sample. In this subsample, all of our key results are robust to including beta in the regressions.

${ }^{25}$ See Table 2 for average declines in stock price: 83 percent for connected firms and 77.7 percent for unconnected firms in this first phase of the crisis.
} 
In the last three columns, we include separate dummies for PMC and FMC. Both types of politically connected firms had worse stock price performance than did unconnected firms but the difference in performance between PMC and FMC firms is small in this time period. Among non-financial firms, PMC firms had a greater decline of 7.9 percentage points, and FMC firms had a greater decline of 5.9 percentage points.

Note that depending on the precise specification, as many as six of the 12 industry dummies are significant in our "crisis period" regressions. ${ }^{26}$ However, including industry dummies does not weaken the coefficients on the political connection variables.

In the first phase of the financial crisis, therefore, political connections were associated with a significant negative effect on the stock price performance of Malaysian firms (although the total decline in all stock prices was larger than the connection-specific effect). This is broadly consistent with the Rajan and Zingales (1998) view that firms with strong political connections suffer more in a financial crisis, presumably because the expected value of government support declines. It is hard to know exactly what the Malaysian government was doing with regard to such support in 1997-98, but the Finance Minister's stated policy was to follow tight budget discipline along the lines of a de facto IMF program (although Malaysia did not sign up for official IMF conditionality). There was also a certain amount of political rhetoric regarding the need to reduce cronyism (and various statements from both the Finance Minister and Prime Minister about who was or was not a “crony”). Our results indicate that the market interpreted the policies of July 1997 to August 1998 as squeezing politically connected firms. $^{27}$

\section{F. Effects of Capital Controls: September 1998}

If politically connected firms performed poorly during the first phase of the crisis because the connections themselves decreased in value, then connected firms should rebound more than unconnected firms when capital controls were imposed. (Again, we are measuring not the effects of the controls alone, but rather the market's view-which may have been incorrect—of all the events associated with the controls).

In general, it could be difficult to differentiate a rebound based on political connections from a rebound based on operating characteristics of firms. But Malaysian political events allow for a cleaner test. September 1998 marked both the imposition of capital controls and also the downfall of the Finance Minister. Once considered the Prime Minister's certain successor, the Finance Minister was fired on September 2, 1998 and then jailed on charges of

\footnotetext{
${ }^{26}$ Following Campbell (1996, Table 1) the industries are petroleum, finance/real estate, consumer durables, basic industry, food/tobacco, construction, capital goods, transportation, utilities, textiles/trade, services, and leisure.

${ }^{27}$ We have performed a number of robustness tests of these results that are not reported here but are discussed in Johnson and Mitton (2003). In particular, the regression results are robust to controlling for political favoritism of Bumiputra firms.
} 
corruption on September 20, 1998. Over the course of September 1998, investors' perceptions were that these events reduced the value of political connections for firms with strong ties to the Finance Minister. To the extent that politically connected firms enjoyed a rebound in September due to the increased value of their connections, investors would not expect the same increase in value to be enjoyed by FMC firms.

Table 4 presents the results of regressions of stock returns for September 1998 on the same variables as in Table 3. The first three columns present results for the political connections indicator. Politically connected firms as a whole enjoyed a rebound in September 1998 (their total increase in average stock price was 53.2 percent, compared with 37.1 percent for unconnected firms; see Table 2). Among non-financial firms, a higher return of 8.1 percentage points, not significant at standard levels, may be attributed to political connections. The effect appears to be stronger among financial firms, where connected firms on average had a higher return of 28.5 percentage points, which is significant at the 1 percent level. For all firms combined, the political connections coefficient shows a higher return of 13.8 percentage points, and is significant at the 5 percent level.

The final three columns of Table 4 present results for the differences in PMC and FMC firms. Among non-financial firms, PMC firms on average experienced higher returns of 13 percentage points, significant at the 10 percent level, while the dummy on FMC firms is minus 11.6 percentage points (but is not statistically significant), for a total net difference of 24.6 percentage points (13 plus 11.6) between PMC and FMC firms. The effect seems even stronger among financial firms, where PMC firms had higher returns of 40.3 percentage points, significant at the 1 percent level. Among all firms combined, PMC firms on average had higher returns of 19.9 percentage points, significant at the 1 percent level, while FMC on average had lower returns of 6.3 percentage points (not statistically significant). This result suggests that the value of political connections themselves was an important determinant of the fortunes of Malaysian firms when capital controls were imposed.

As a further test of whether the observed differences are due to the effects of capital controls, we examine cross-sectional differences in stock price gains following the imposition of capital controls. If capital controls constrain financial flows across borders, we would expect to see smaller gains for connected firms having access to international capital markets compared to connected firms without such access. In additional regressions (not reported here but see Johnson and Mitton, 2003) we compare gains for connected firms that had foreign capital access (defined as having international stock listings or bond placements) with connected firms that did not have foreign capital access. While the evidence is mixed at times, on balance the results show that politically connected firms without foreign capital access performed better than connected firms with foreign capital access when capital controls were imposed (Johnson and Mitton, 2003). ${ }^{28}$ The results are consistent with the idea that capital controls affected Malaysian firms’ access to foreign finance.

\footnotetext{
${ }^{28}$ Our results are weakest when we limit the sample to just firms that were included in the IFC's investable index, i.e., those regarded as being more liquid. In this case, the coefficient on Prime
} 


\section{G. Economic Significance of Political Connections}

For a measure of economic significance, we use our regression coefficients to estimate the impact of connections on the total market value of firms. We find that during the crisis period, roughly $\$ 5.7$ billion of the total market value lost by connected firms is attributable to their political connections. When capital controls were imposed in September 1998, although market valuations were then on a smaller scale, political connections are estimated to have accounted for an incremental gain of roughly \$1.3 billion in market value for connected firms. ${ }^{29}$

By looking at the outcomes for connected firms in September 1998, we can obtain an estimate of the perceived value of political connections as a percentage of total firm value after capital controls were imposed. If we assume that the events of September 1998 restored the full value of connections to the Prime Minister, then the estimated gain attributable to PM-connections in September 1998 should give an indication of the percentage of firm value attributable to political connections. Our regression coefficients show that PM-connections account for about a 20 percent increase in firm value in September 1998. In terms of (higher) valuations at the end of September 1998, this increase would be 12 percent of firm value. This would suggest that 12 percent is a low estimate of investors' perceptions of the percentage of firm value attributable to connections, with the actual percentage being higher to the extent that connections still accounted for some value prior to September 1998. While this is clearly only a rough estimate, the estimated proportion of value attributable to connections seems to be within the 12 percent to 23 percent range estimated by Fisman (2001) for connected firms in Indonesia.

Regarding the effect of political connections in relation to the total variation in returns, we note that in regressions with September 1998 returns, the R-squared of the regression rises incrementally from 0.109 to 0.143 when the political connection variables are added. This suggests that roughly 3.4 percent of the total variation in returns is explained by differences in political connections (alternatively, about $1 / 4$ of the systematic, explainable variation in stock prices is due to political connections). For regressions of returns for the initial crisis period, adding political connection variables increases the R-squared from 0.210 to 0.237 , suggesting that 2.7 percent of the total variation in returns is explained by differences in political connections.

Minister connections falls to 0.129, with a t-statistic of 1.1. However, this sample is only 109 firms, which is about $1 / 4$ of our main sample, so the loss of significance is not surprising.

${ }^{29}$ The estimates of the effects of political connections on market value are based on our estimated regression coefficients, monthly stock prices, and available data on the number of shares outstanding for each firm. Because the number of shares outstanding is not known for every month and is missing for three of the connected firms, the estimated figures are not exact calculations, but reasonable estimates. 


\section{H. After Imposition of Capital Controls: 1999-2003}

What did the Malaysian government do once capital controls were imposed? Some general reflationary measures were taken, including cutting interest rates and making credit more readily available to consumers and firms (Kaplan and Rodrik, 2001; Mahathir, 2000, Ch. 8). A new expansionary budget was introduced in October 1998 (Perkins and Woo, 2000). Overall, however, as discussed above, macroeconomic policy remained cautious and responsible after the controls were imposed.

At the firm level, evidence from the public record suggests that the government may have used the economy's isolation from short-term capital flows to restore advantages for some favored firms. The precise distribution of these advantages is hard to measure, as they are usually not reported publicly. However, high-profile incidents that have been reported in the international media suggest three types of benefits for favored firms. ${ }^{30}$

First, the state-owned oil company was called upon to provide bailouts to particular distressed firms (see, e.g., Jayasankaran, 1999a, Restall, 2000a, Lopez, 2001). ${ }^{31}$ Second, some companies with perceived political connections appeared to receive advantageous deals directly from the government (see, e.g., Prystay, 2000, Asian Wall Street Journal weekly edition, July 31-August 6, 2000). ${ }^{32}$ Third, in the banking sector, the government introduced a consolidation plan that appeared beneficial to connected firms, and some large companies were allowed to repeatedly roll over their debts (see, e.g., Jayasankaran, 1999b, Dhume, Crispin, Jayasankaran, and Larkin, 2001). ${ }^{33}$

\footnotetext{
${ }^{30}$ These three forms of advantages for favored firms could benefit minority shareholders, in part because they put the supported firms on a stronger financial basis and reduce the incentives to transfer resources out of the firms (Johnson, and others, 2000). In other cases, however, the government has permitted companies to carry out actions that might be detrimental to minority shareholders (see, e.g., Restall, 2000b; Perkins and Woo, 2000; Jayasankaran, 2000).

31 "Since the Asian financial crisis hit, Petronas has helped buy debt-burdened shipping assets controlled by Mahathir's eldest son; now it's preparing to buy control of the national car maker, Proton. Looking ahead, Mahathir told the REVIEW in June that he didn't see why Petronas should not take over the ailing national carrier, Malaysian Airlines, although Petronas itself says it has no such plan" (Jayasankaran, 1999a).

32 "On Friday, the government announced it will raise six billion ringgit (\$1.58 billion) in a bond issue to buy back the assets of two unprofitable privatized light-rail projects in Kuala Lumpur. Two key beneficiaries of the bailout: debt-laden conglomerate Renong Bhd., which owns one of the rail projects, and Renong's controlling shareholder, Halim Saad. The move comes days after the Finance Ministry agreed to repurchase a 29 percent interest in ailing Malaysian Airlines System from businessman Tajudin Ramli for 1.79 billion ringgit--the same price he paid the government for the MAS stake in 1994" (Prystay, 2000).

33 "A major worry is that the government seems to have weighed political ties in choosing some of the leader banks... Just as there are losers in the merger stakes, so are there winners. One of them is Multipurpose Bank, a small institution controlled by businessmen widely viewed by analysts as being close to Finance Minister Daim" (Jayasankaran, 1999b).
} 
While these extracts from the public record provide anecdotal evidence that certain firms were favored after the imposition of capital controls, it is impossible to directly measure the extent to which connected firms received benefits. In order to address the issue more systematically, we turn again to the firm-level data. Specifically, we examine the operating performance of all Malaysian firms in Worldscope over the period 1990-2003. We study four firm-level measures of operating performance: investment, growth, profitability, and leverage. Here we define investment as the ratio of capital expenditures to gross fixed assets, growth as the log annual growth rate in sales, profitability as the return on assets, and leverage as the ratio of total debt to total assets.

In Table 5, we show the median firm-level operating performance for each of these measures for each year from 1990 to 2003. To assess the effect of having political connections in each year, we also show the results of regressing these performance measures on a full set of 2digit SIC sector dummy variables, a control for firm size, and a dummy for whether a firm was, according to Gomez and Jomo (1997), connected to the Prime Minister. Each year is covered in a separate regression.

The results in Table 5 indicate that PMC firms showed higher investment, higher growth, higher leverage, and lower profitability in most pre-crisis years (compared with non-PMC firms). However, in the years following the crisis, the differences in investment and growth largely were reversed - the PMC firms have lower investment and growth. In addition, in the years following the crisis, PMC firms appear to have had even higher leverage than other firms compared with the years before the crisis. On balance, the results show that the effects of being connected to the PM, in terms of firm operating performance, were very different after the imposition of capital controls from what they were prior to the crisis.

To further assess the operating performance of connected firms, in Panel A of Table 6, we estimate the following panel regression:

$$
\text { Performance }_{i t}=\alpha+\text { Firm }_{i}+\text { PMC }_{i} \times \text { Crisis }_{t}+\text { PMC }_{i} \times \text { Post-crisis }_{t}+\text { Year }_{t}+\varepsilon_{i t} .
$$

Where Performance $e_{i t}$ is one of the four measures of operating performance for firm $i$ in year t. Firm $_{i}$ represents firm-fixed effects. $P M C_{i}$ is a dummy variable indicating whether firm $i$ is connected to the Prime Minister. As we have a full set of firm-fixed effects, we cannot estimate the direct PMC effect, but this framework allows us to look at how the effects of connections varied over time. Crisis $s_{t}$ is a dummy variable set to one for years 1997-1998, and Post-crisis $t$ is a dummy variable set to one for years 1999-2003. Year $_{t}$ represents a full set of year-specific dummy variables.

These results show that compared with unconnected firms, PMC firms suffered a large drop in relative investment and growth from the pre-crisis to post-crisis period. They also had less growth and higher leverage, relative to unconnected firms, in the crisis period compared with 
the pre-crisis period. The effects in question are large and consistent with the data shown in Table $5 .^{34}$

However, it is possible that the standard errors in Panel A, Table 6 are too low, for example if there is serial correlation in the error term. As a more conservative approach, in Panels B, $\mathrm{C}$, and $\mathrm{D}$, we estimate the following cross-sectional regression:

$$
\text { Avg.Performance }_{i}=\alpha+\text { PMC }_{i}+\text { Industry }_{i}+\varepsilon_{i} \text {, }
$$

where Avg.Performance $e_{i}$ is the average of one of the four performance measures over all years in the pre-crisis period (Panel B), the crisis period (Panel C) or the post-crisis period (Panel D). $P M C_{i}$ is a dummy variable indicating whether firm $i$ is connected to the Prime Minister. Industry $y_{i}$ represents a full set of industry dummy variables. ${ }^{35}$

In addition, Panel A, Table 6, show the value of PMC after the crisis relative to PMC before (or during) the crisis. Panels B, C, and D show the PMC vs. unconnected (non-PMC) comparison within each time period, which enables us also to check the absolute value of these connections. PMC firms had a growth advantage in the pre-crisis period, and that this disappeared after the crisis. ${ }^{36}$ These connected firms also had more leverage and less profitability during the crisis. Taken with the rest of Table 6 and Table 5, these results suggest that PMC firms' advantages were not manifest in better performance after the resolution of the crisis. ${ }^{37}$

\section{Conclusion}

We do not find evidence that Malaysia's September 1998 controls were essential for recovery or structural reforms. Our analysis of the key macroeconomic and financial indicators confirms the empirical findings of Hutchinson (2001) that Malaysia's macroeconomic performance after the imposition of capital controls was comparable to other countries recovering from the Asian financial crisis. The controls were imposed late, after a big depreciation and after a large amount of capital had already left the country, and this limited the potential macroeconomic benefits. At best, the controls played a preventive role in guarding against perceived risks to financial stability, but in this role they were not tested by any observable pressure. As far as we can determine, Malaysia’s successful recovery resulted

\footnotetext{
${ }^{34}$ We obtain similar results for investment, leverage and profitability using Arellano-Bond GMM. A balanced panel also gives similar results, although the standard errors are higher because the sample is much smaller (about 20 percent of the full sample).

${ }^{35}$ The only difference between the regression in the Table 5 and the one in Table 6, Panels B, C, and $\mathrm{D}$, is that Table 5 also includes a control for firm size.

${ }^{36}$ In panels B, C, and D, the results are very similar if we use the same set of firms in each.

${ }^{37}$ Tables 5 and 6 include both financial and nonfinancial firms. We ran the same regressions separately for non-financial firms only, without finding any significant differences.
} 
from the country's strong fundamentals, sound policies, and effective institutions, rather than from the capital controls. It would thus be misleading to draw any general lessons applicable to other countries based on Malaysia's experience with capital controls during the Asian crisis.

The firm-level evidence from Malaysia, however, supports the idea that the stock market interpreted the events of September 1998 as helping politically connected firms (relative to unconnected firms). Firms with political connections were expected by the stock market to lose benefits in the first phase of the Asian crisis. Conversely, firms connected to the Prime Minister were expected to gain benefits when capital controls were imposed in September 1998.

The presence of political connections in East Asian economies does not mean that these connections caused the crisis or even that relationship-based capitalism was necessarily a suboptimal system for these countries. While politically connected firms were hit harder during the crisis, the data do not indicate that this was a punishment for past misdeeds and deficiencies. The evidence suggests rather that investors interpreted the crisis as indicating that previously favored firms would lose valuable advantages, while the imposition of capital controls indicated — at least initially — that these advantages would be restored for some firms.

Based on the actual financial performance of firms after the crisis, it is hard to discern the extent to which firms actually received special advantages. This could be because financial and corporate sector reforms resulted in fewer advantages for connected firms or because connected firms did not end up making good use of their privileges. 


\section{APPENDIX}

\section{Coding of Firms}

We code as "politically connected” any firm that Gomez and Jomo (1997) identify as having officers or major shareholders with close relationships with key government officialsprimarily the Prime Minister and the Finance Minister (and their allies). For example, Gomez and Jomo (1997) state that [Firm A] is "controlled by [Person X], who is closely linked to [an ally of the Prime Minister] (p. 103), so [Firm A] is coded as politically connected, with the Prime Minister as the primary connection (Gomez and Jomo reveal actual names; we have dropped these here). As another example, Gomez and Jomo (1997) state "The chairman of [Firm B] was [Person Y] of the [Group J], a close friend of [the] Prime Minister” (p. 59). Thus, [Firm B] is coded as politically connected with its primary connection listed as the Prime Minister. As a final example, Gomez and Jomo (1997) state "[Firm C] (in which [Person Z], probably [the Finance Minister's] closest confidant, has an interest...)" (p. 57). This results in [Firm C] being coded as politically connected, with the Finance Minister as the primary connection. We search the entire text of Gomez and Jomo (1997) for all such indications of connections and code them accordingly. ${ }^{38}$

${ }^{38}$ The detailed coding is available from the authors upon request. 
Figure 1. Malaysia: Cumulative and Net Portfolio Flows, 1997-2000

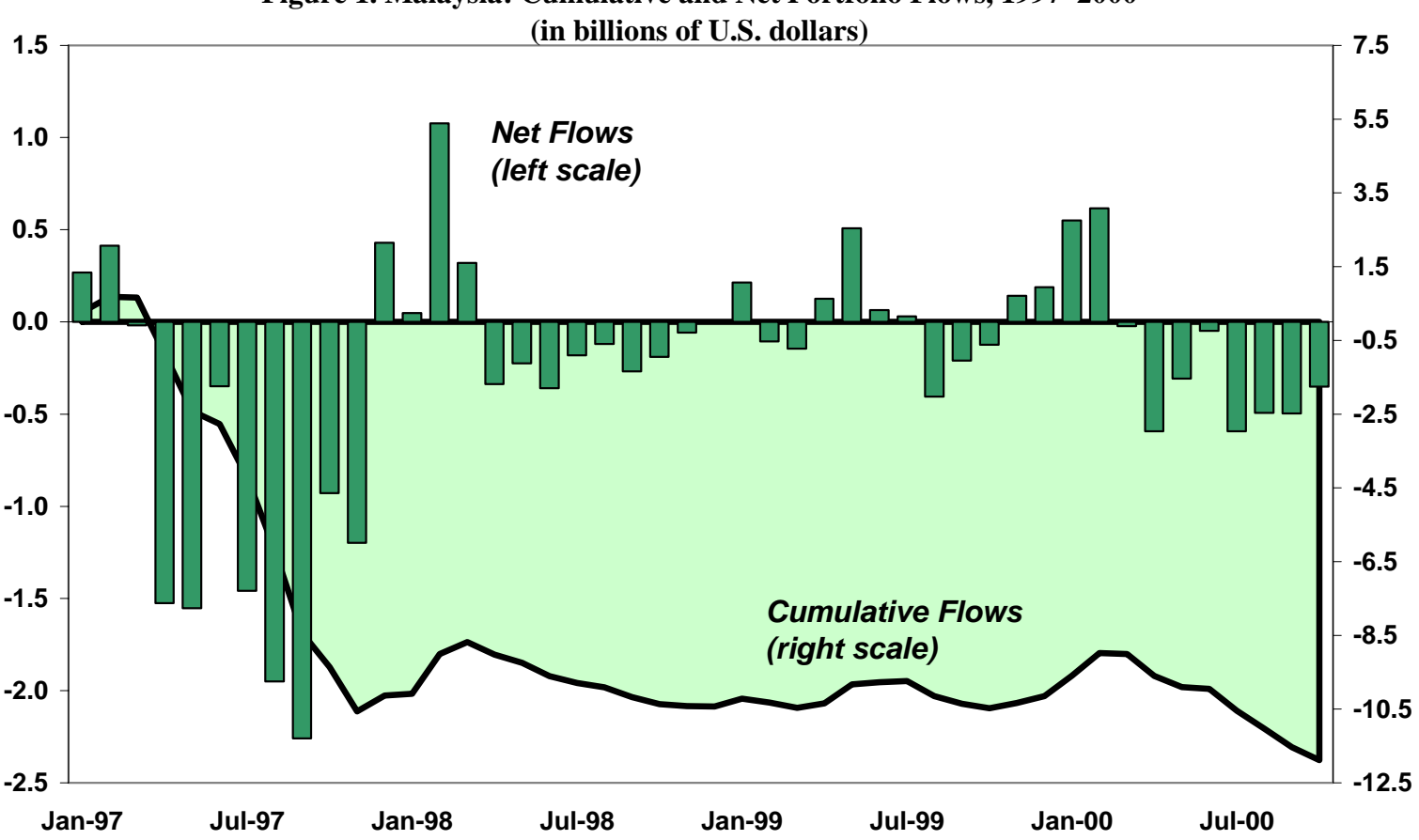

Source: Meesook and others (2001).

Figure 2. Malaysia: International Reserves and Exchange Rate, 1995-2002

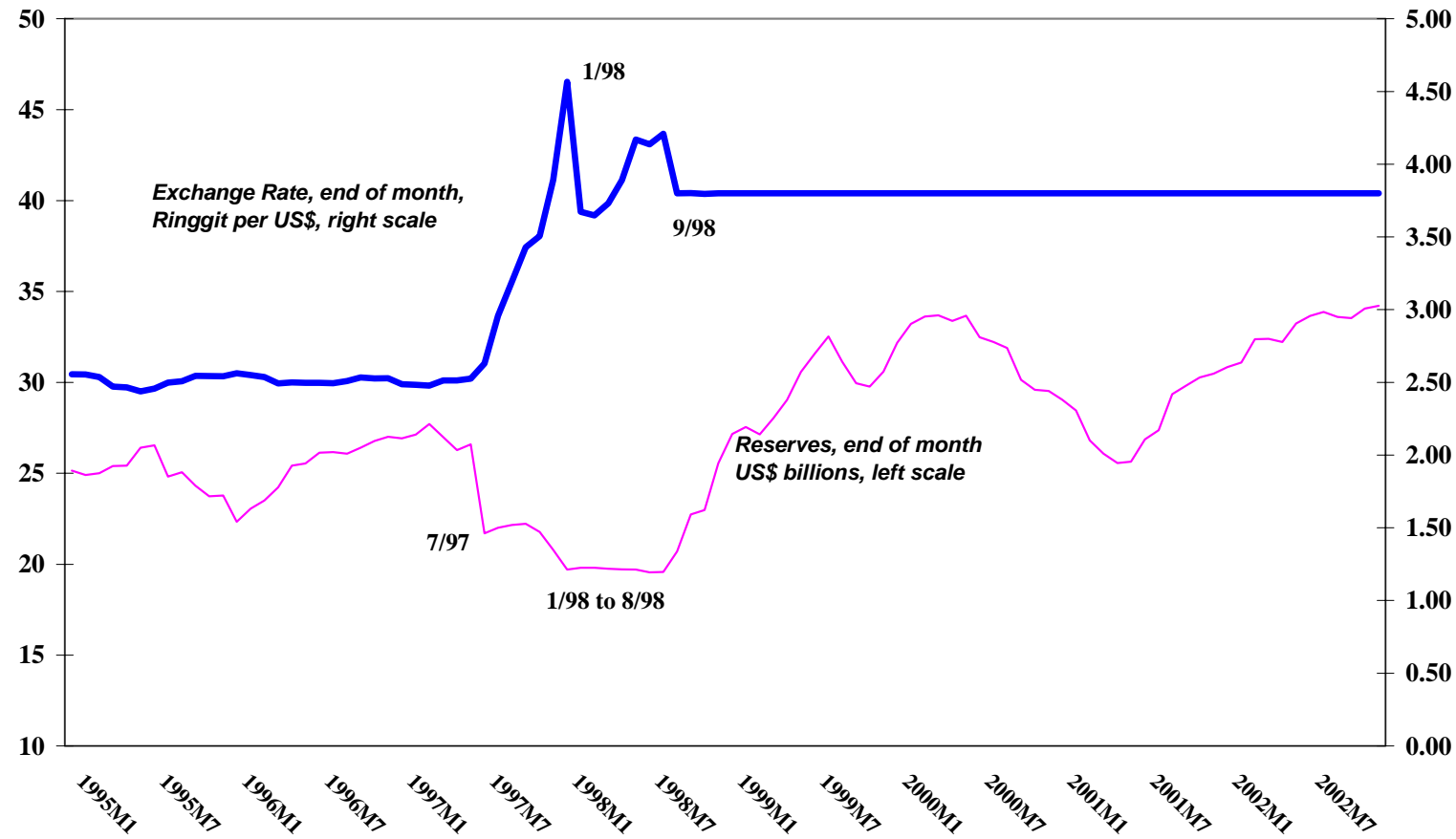

Source: IMF, International Financial Statistics database. 
Figure 3. Malaysia and Thailand: Swap Differentials, May-December $\mathbf{1 9 9 8}^{1}$

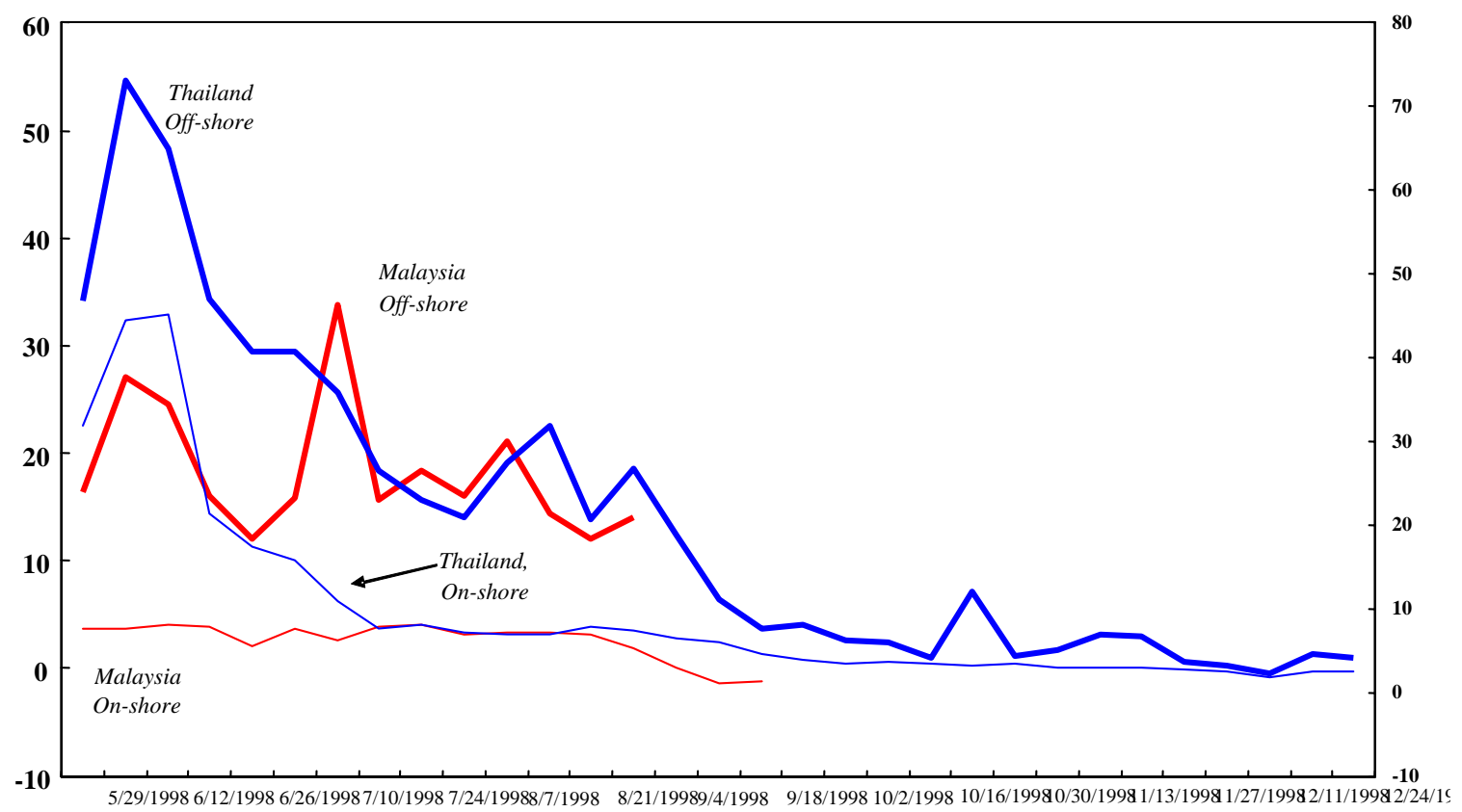

Sources: Data provided by the authorities; Consensus Economics Inc., Asia Pacific Consensus Forecasts; and IMF staff estimates. 
Figure 4. Selected Asian Countries: Monetary Indicators, 1998-2001

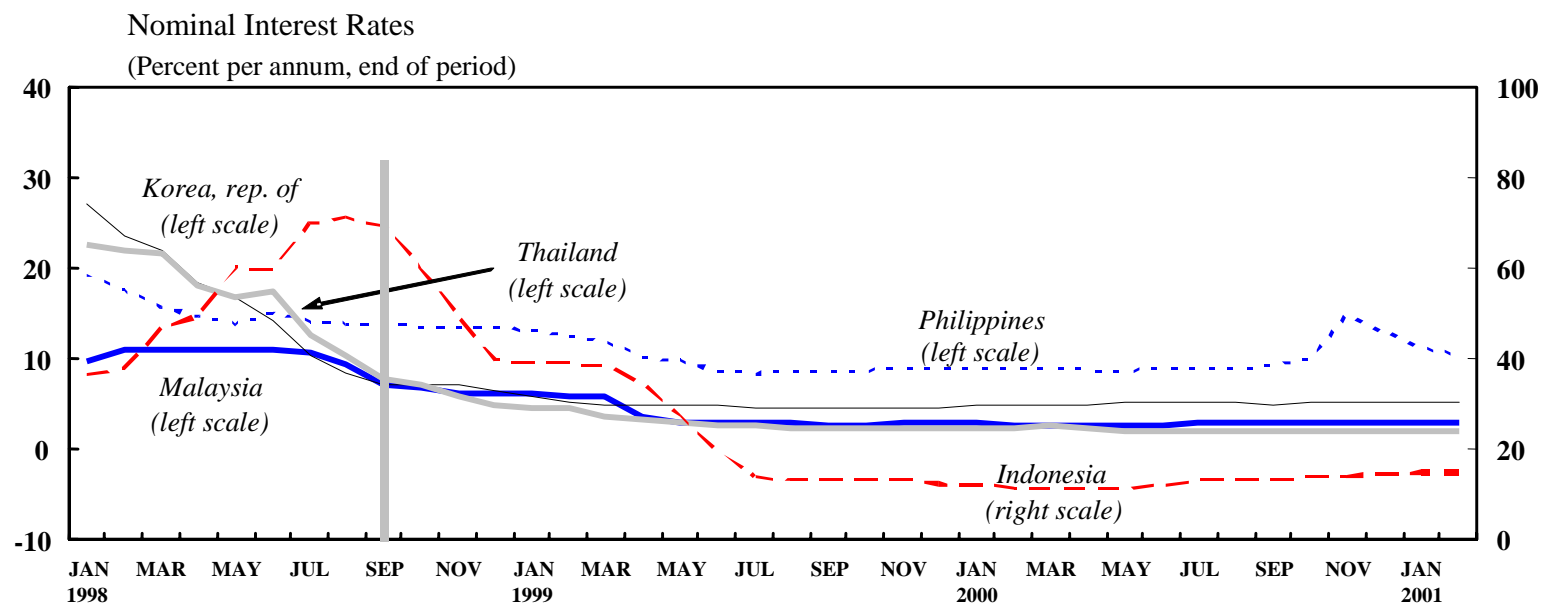

Real Interest Rate

(Percent per annum, end of period)

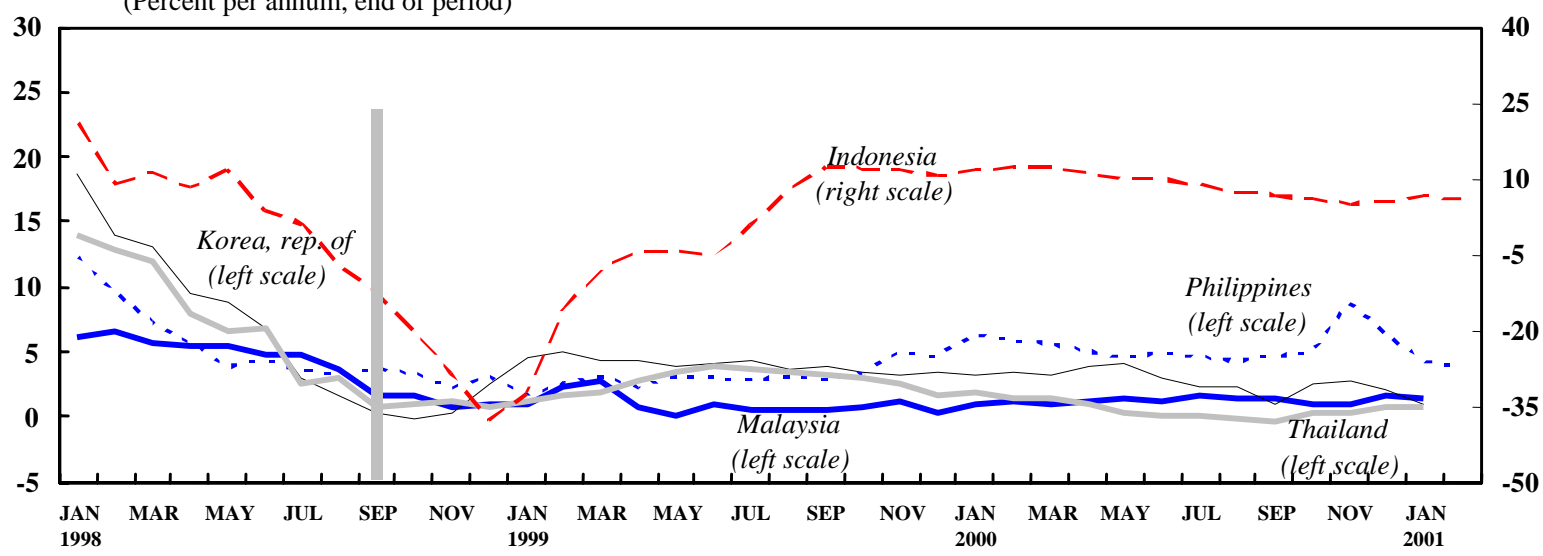

Private Sector Credit Growth

(12-month percent change)

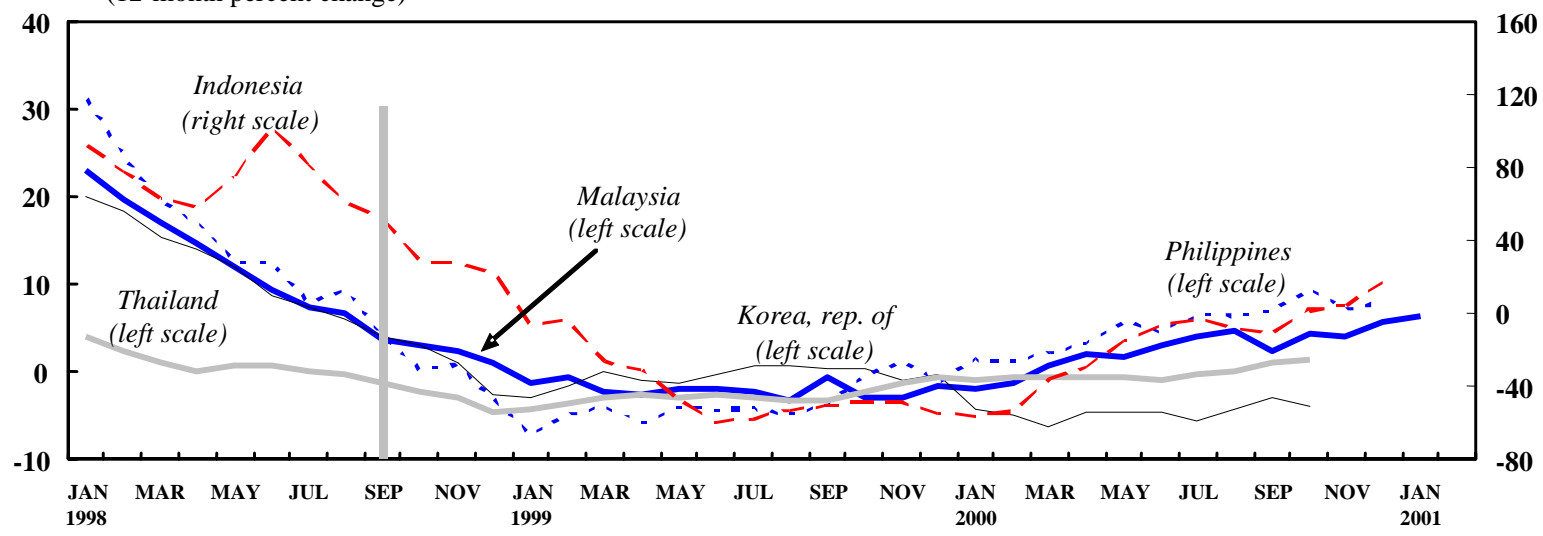

Sources: IMF, International Financial Statistics and Asia Pacific Department databases. 
Figure 5. Selected Asian Countries: Real GDP Growth, 1996-2001
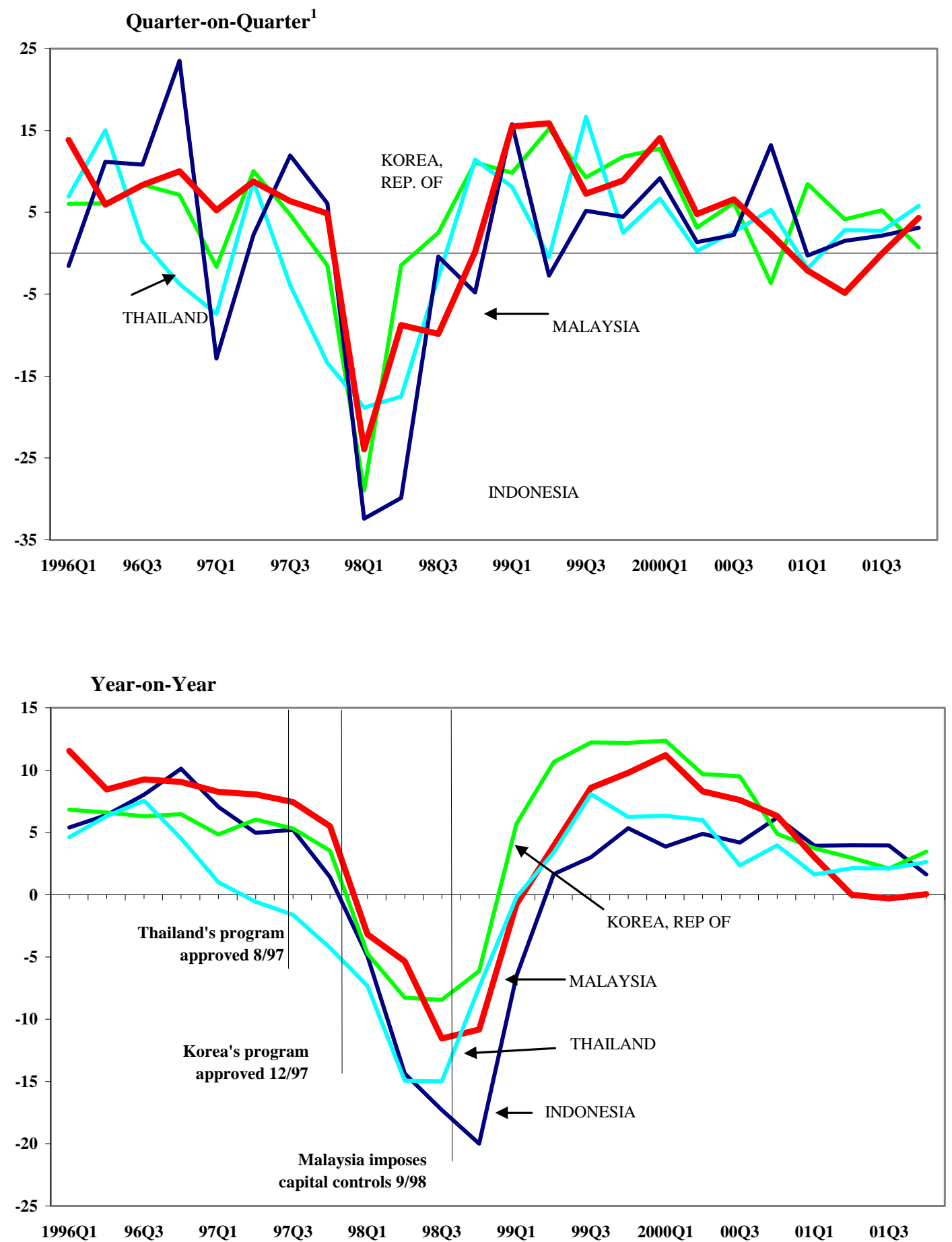

Sources: IMF, Asia Pacific Department Database for Indonesia, the Republic of Korea, and Thailand, Haver Analytics for Malaysia, and IMF, International Financial Statistics database.

1/ Annualized; seasonally adjusted. 
Figure 6. Selected Asian Countries: Political Risk Index, 1995-2002

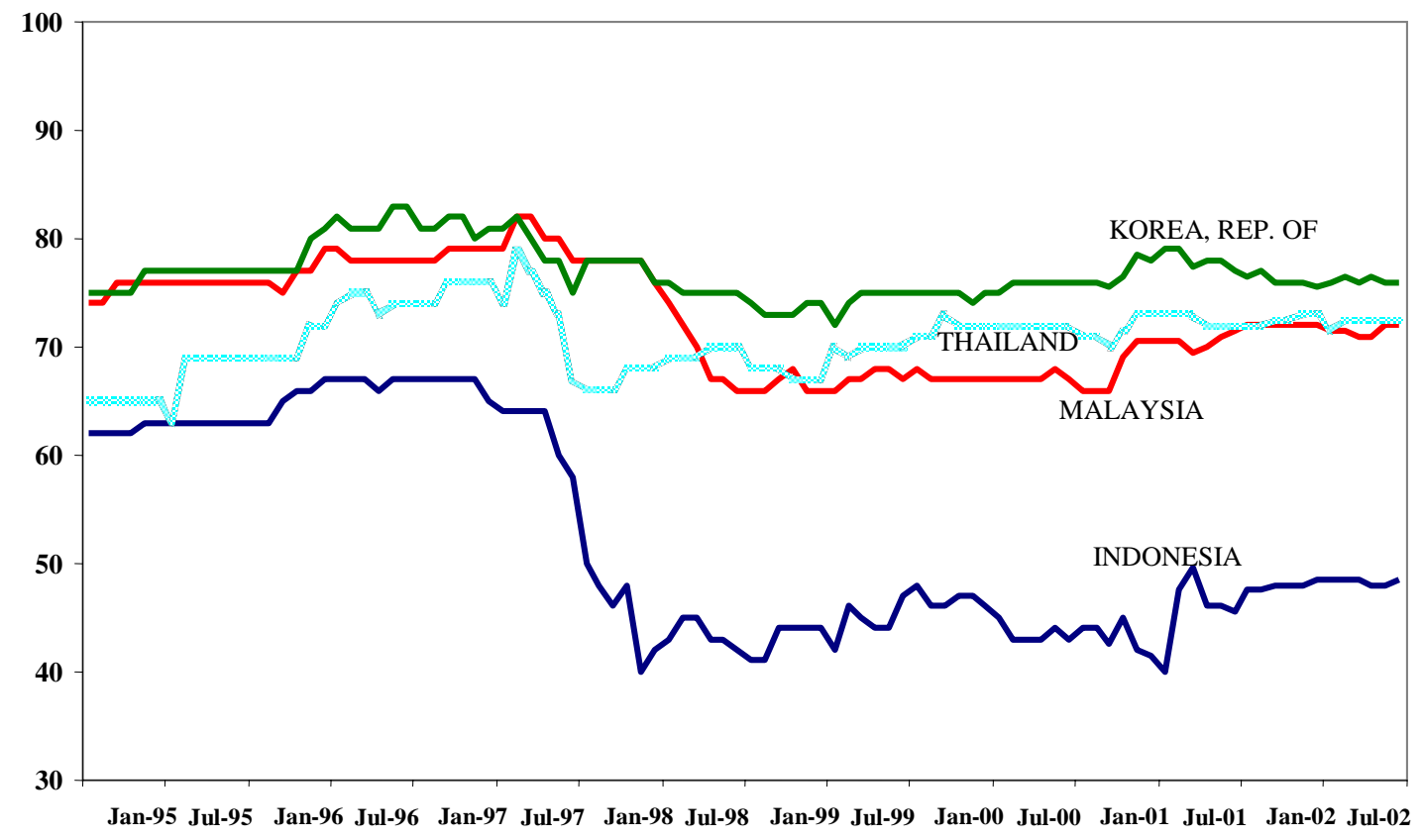

Source: International Country Risk Guide, available on the Web at www.ICRGonline.com. 
Figure 7. Governance Indicators in Percentile Rankings, 1998

Malaysia and East Asia

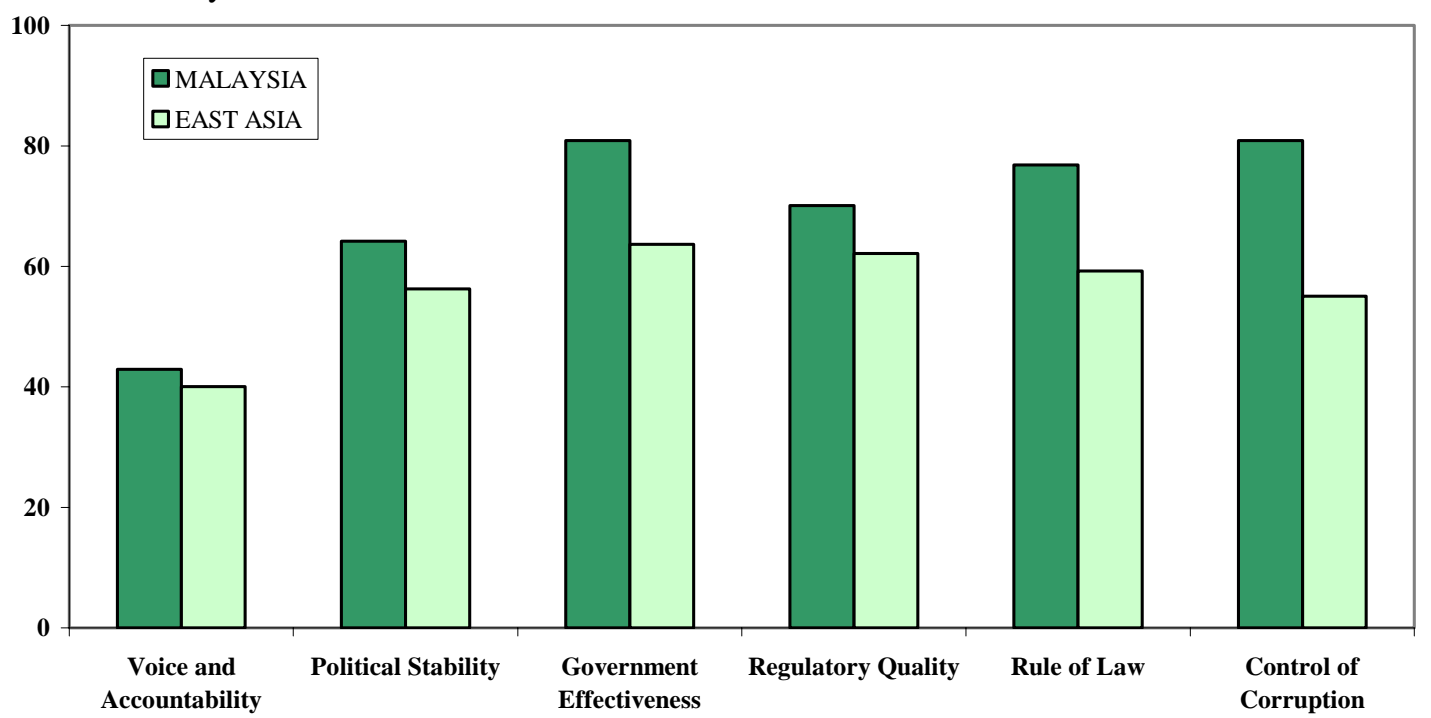

Malaysia and Upper-Middle-Income Countries

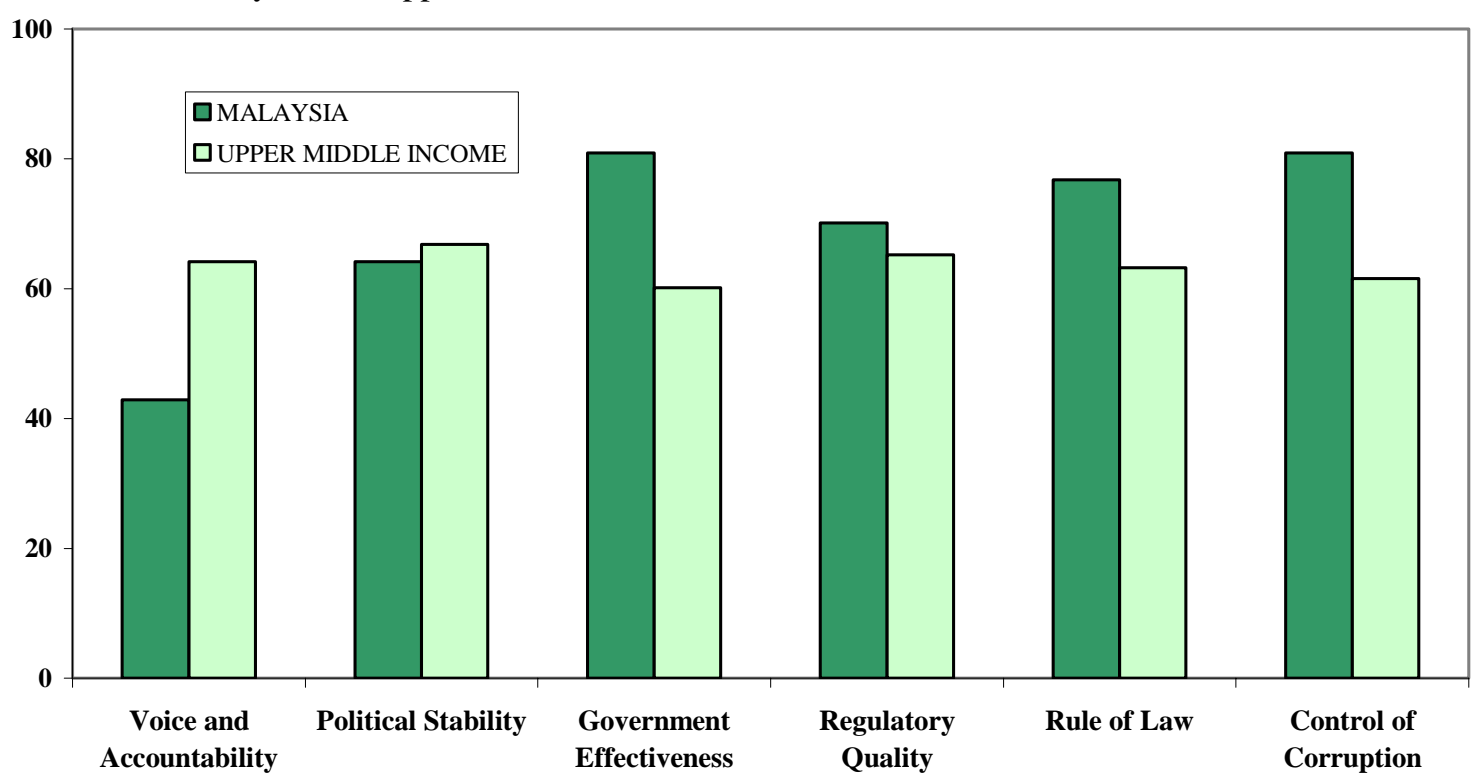

Noates:

The upper-middle-income countries, according to the World Bank's classification, is represented by the average value of the following group: Argentina, Belize, Botswana, Chile, Costa Rica, Croatia, the Czech Republic, Dominica, Estonia, Gabon, Grenada, Hungary,

Latvia, Lebanon, Lithuania, Mauritius, Mexico, Oman, Panama, Poland, Saudi Arabia, Seychelles, the Slovak Republic, St. Kitts \& Nevis,

St. Lucia, Trinidad and Tobago, Uruguay, and Venezuela.

Source: Kaufmann, Kraay and Mastruzzi (2005). 
Figure 8. Asian Countries: Fiscal Indicators, 1995-2000 (in percent of GDP)

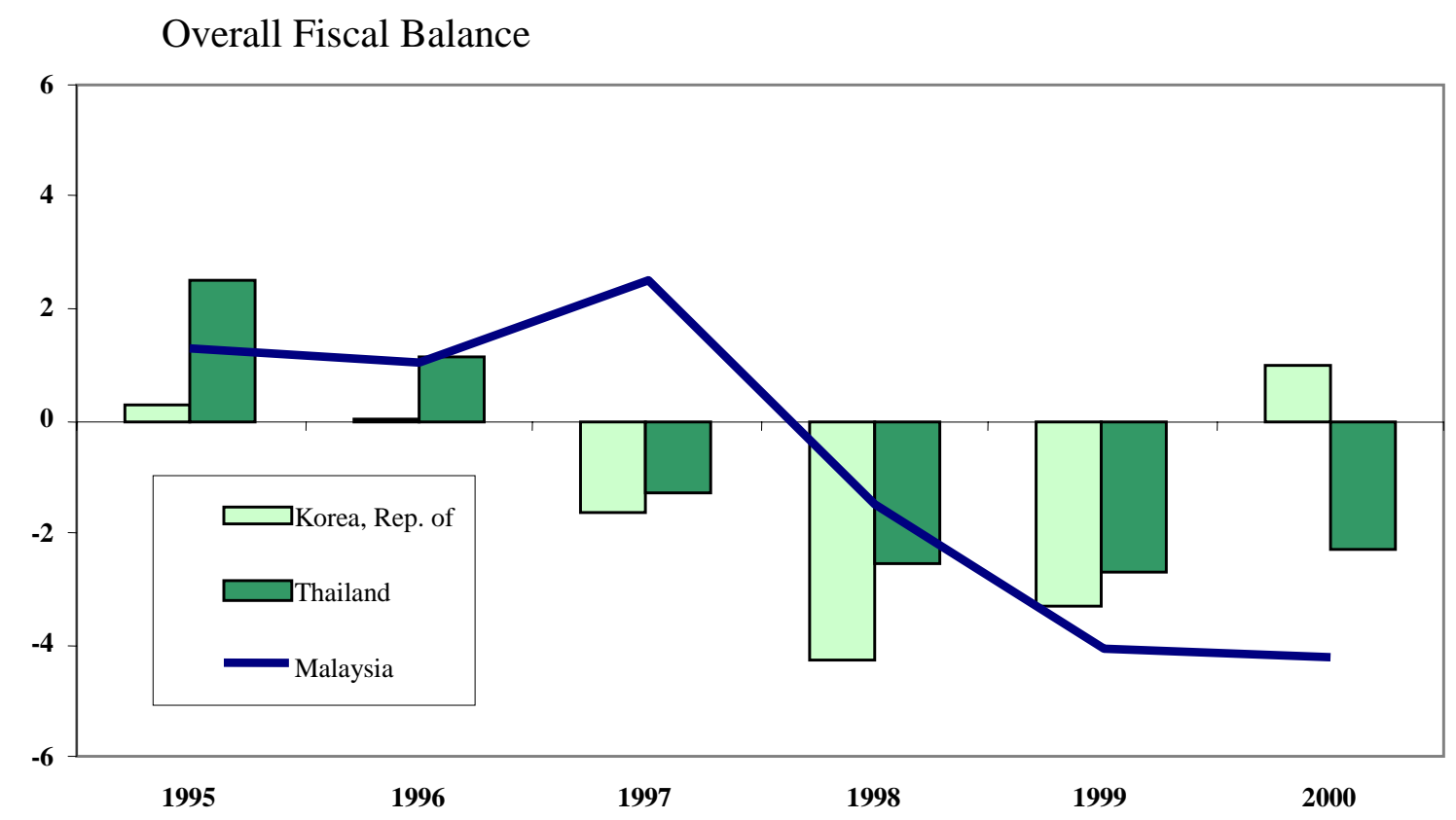

Cumulative Fiscal Impulse

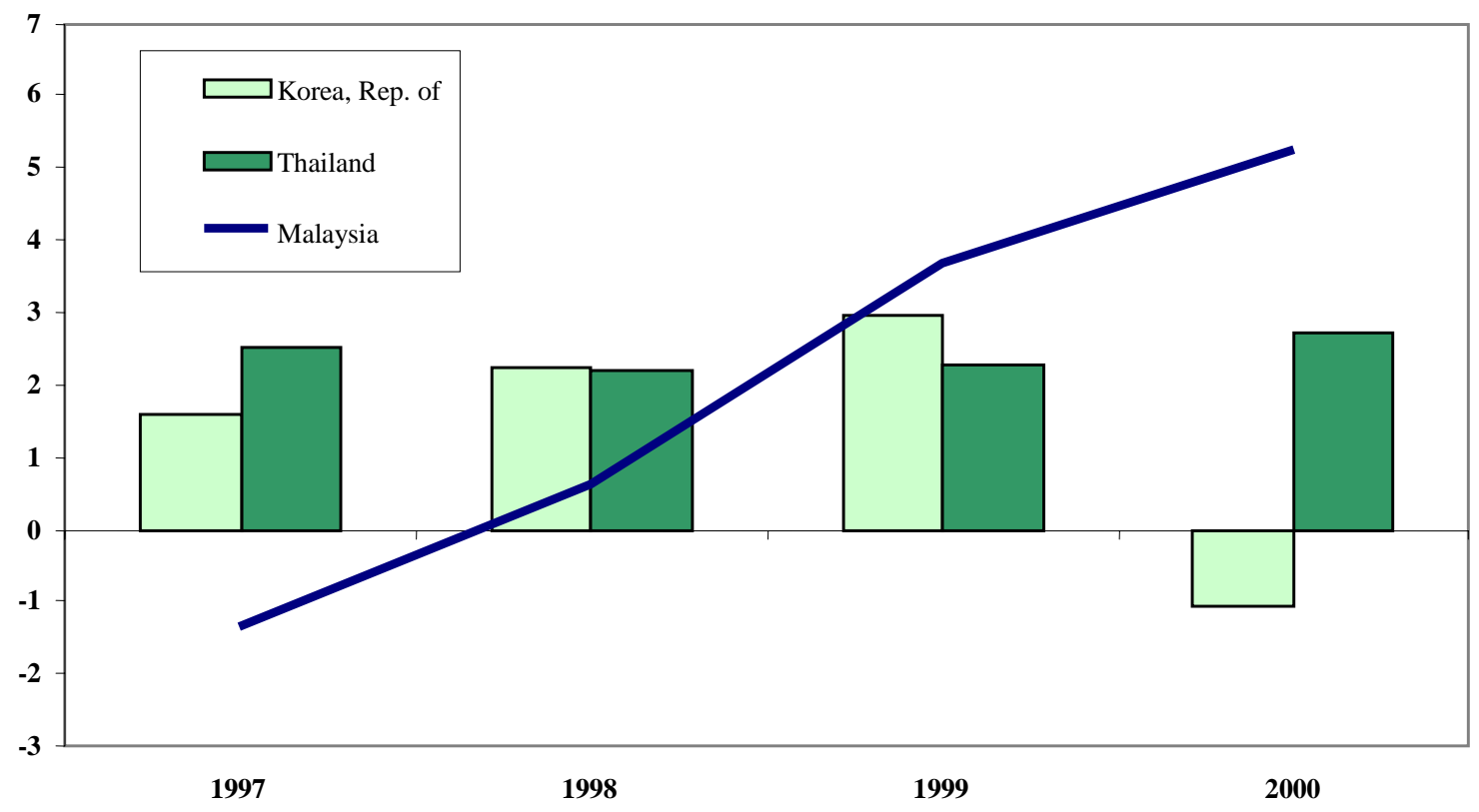

Source: Meesook and others (2001). 
Figure 9. Selected Asian Countries: Private Fixed Investment, 1990-2004 (private gross fixed capital formation as percent of GDP)

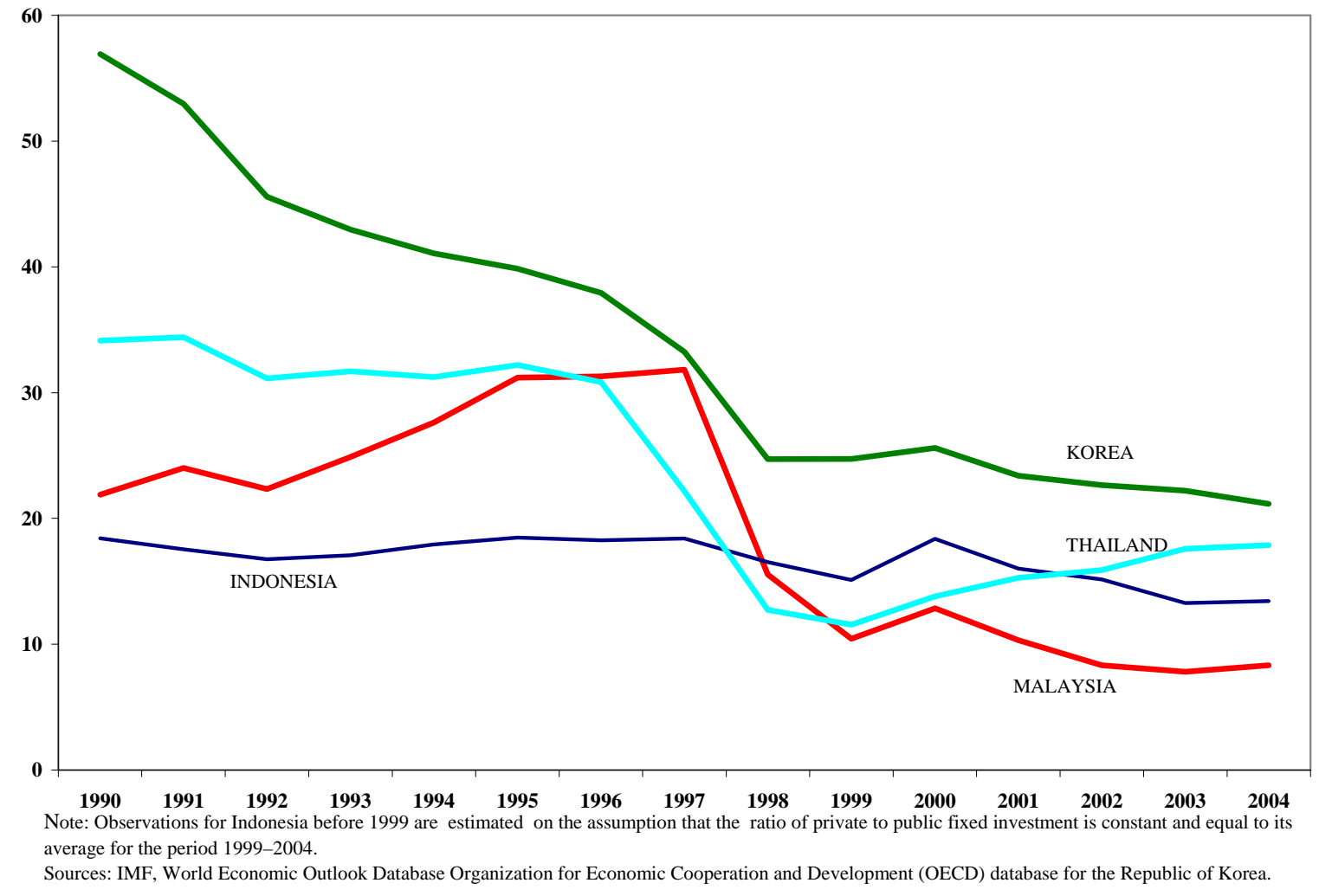




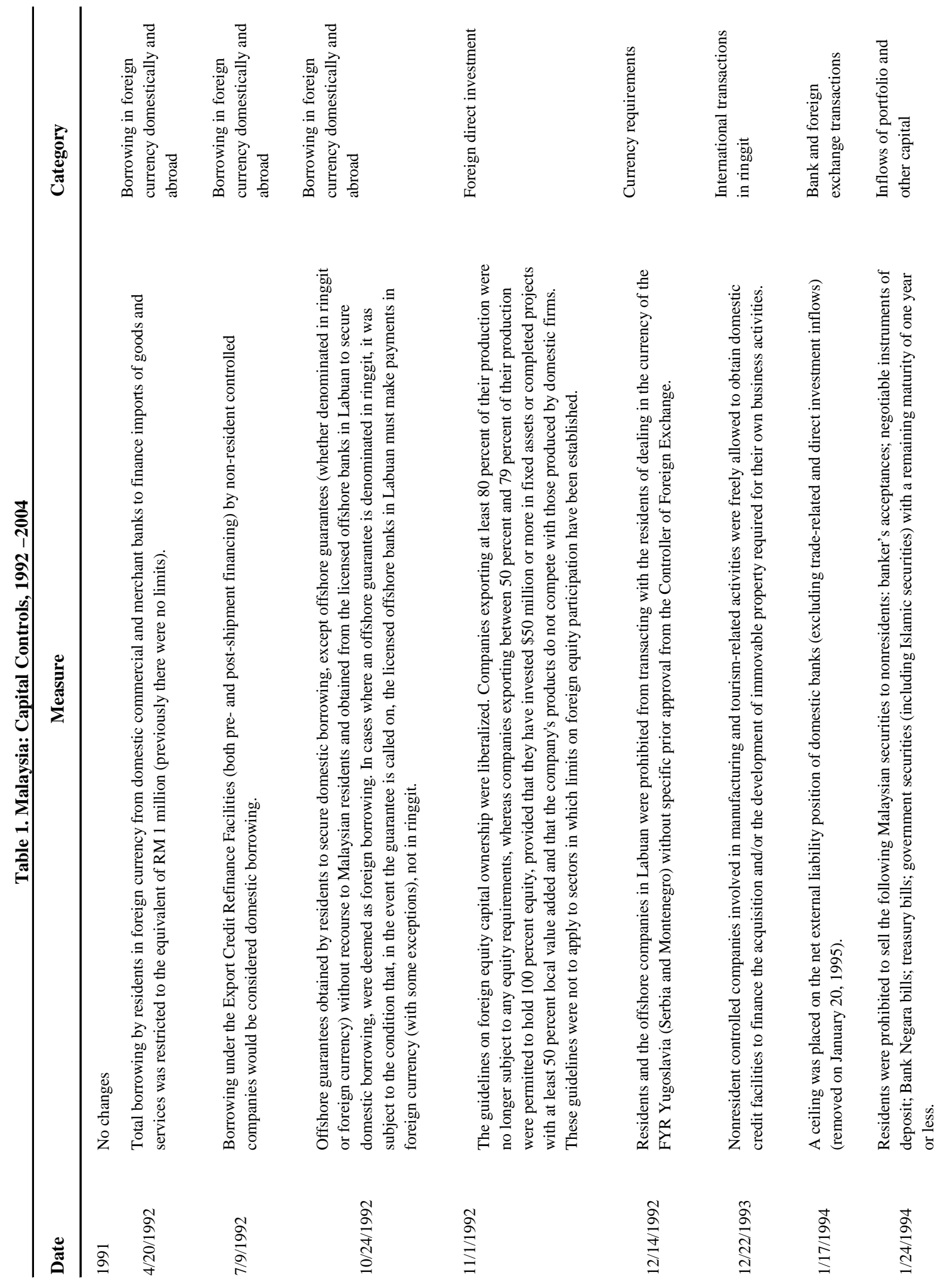



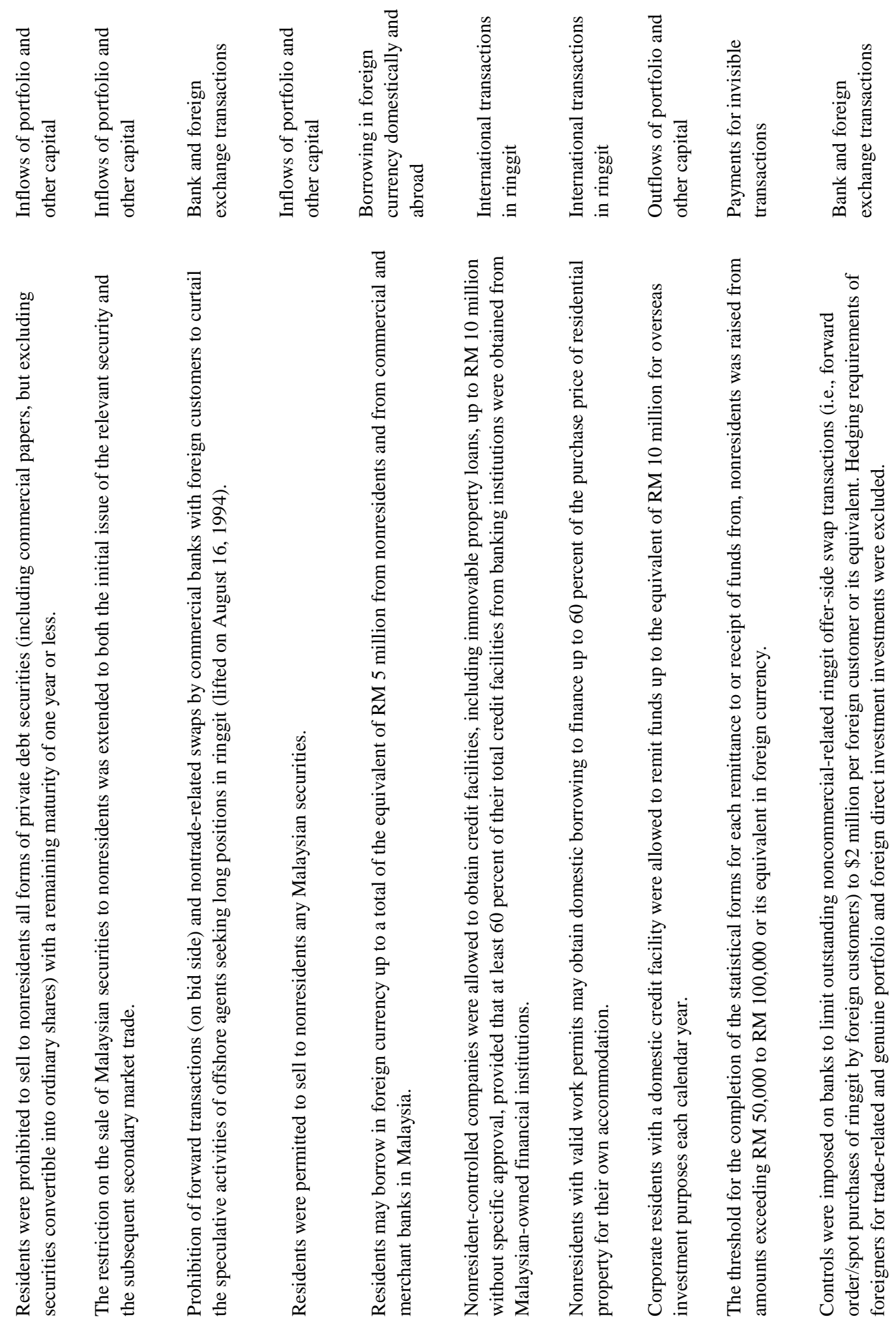

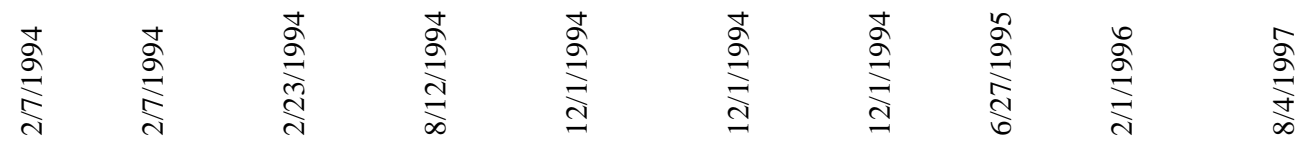



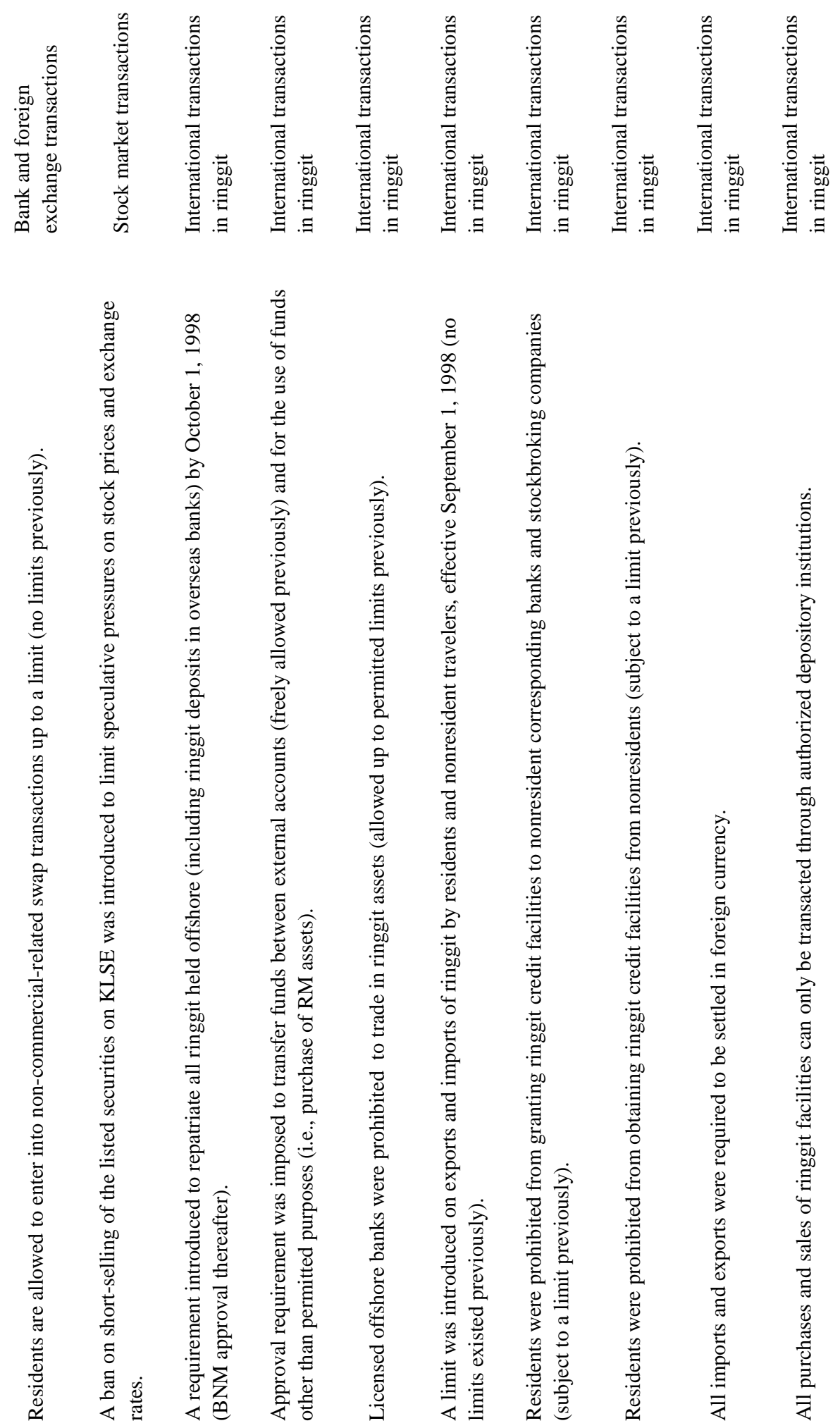

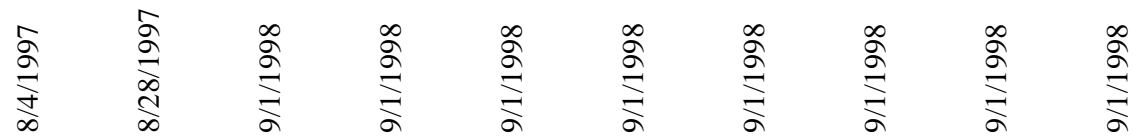



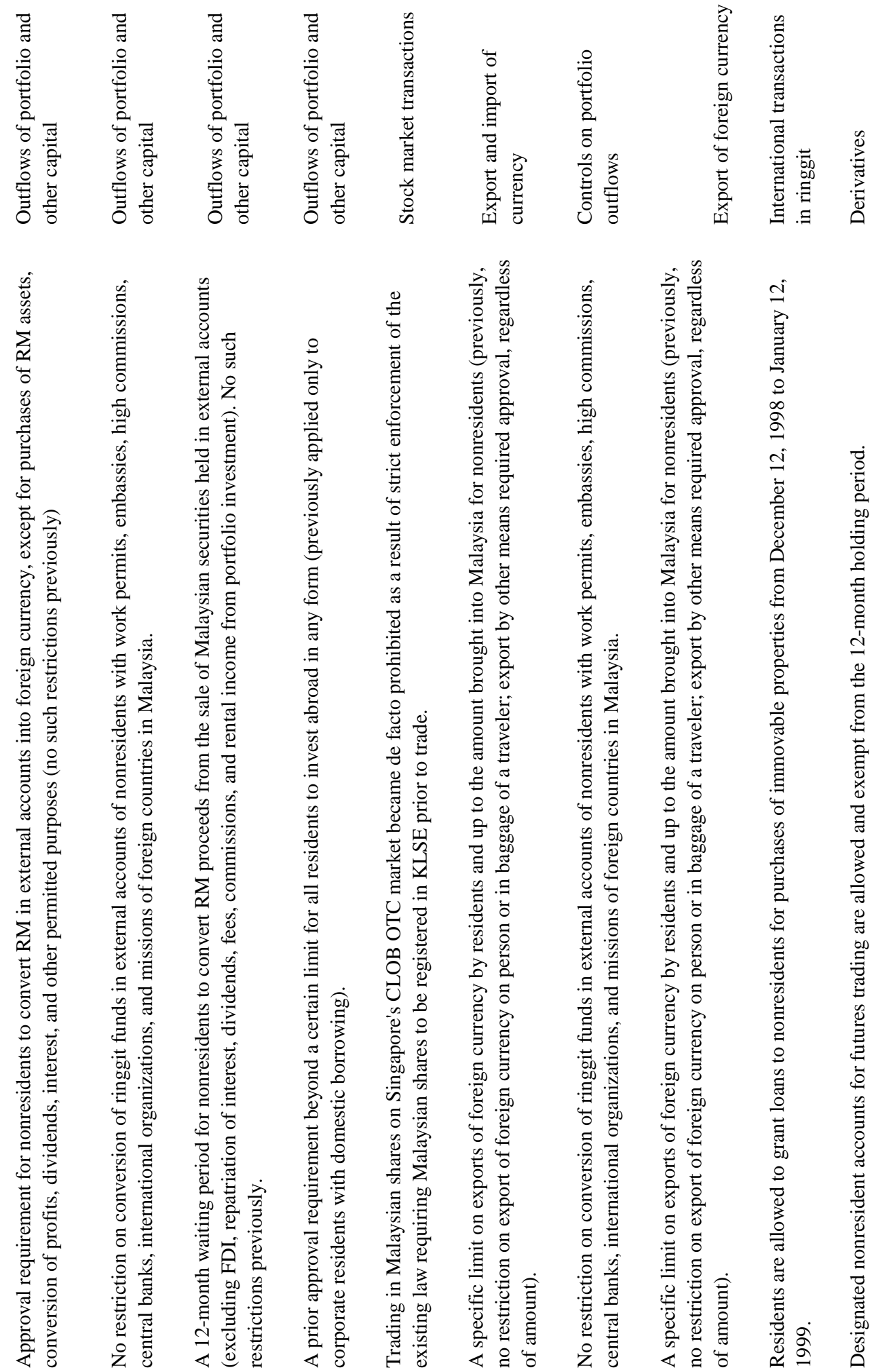

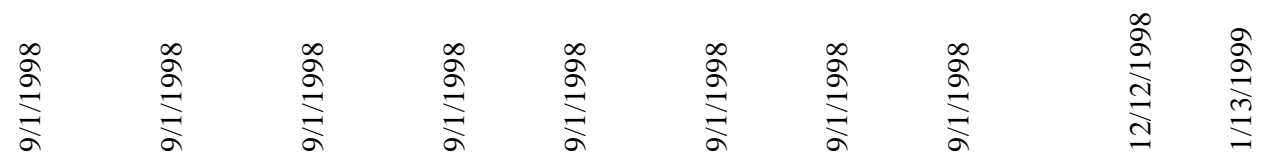



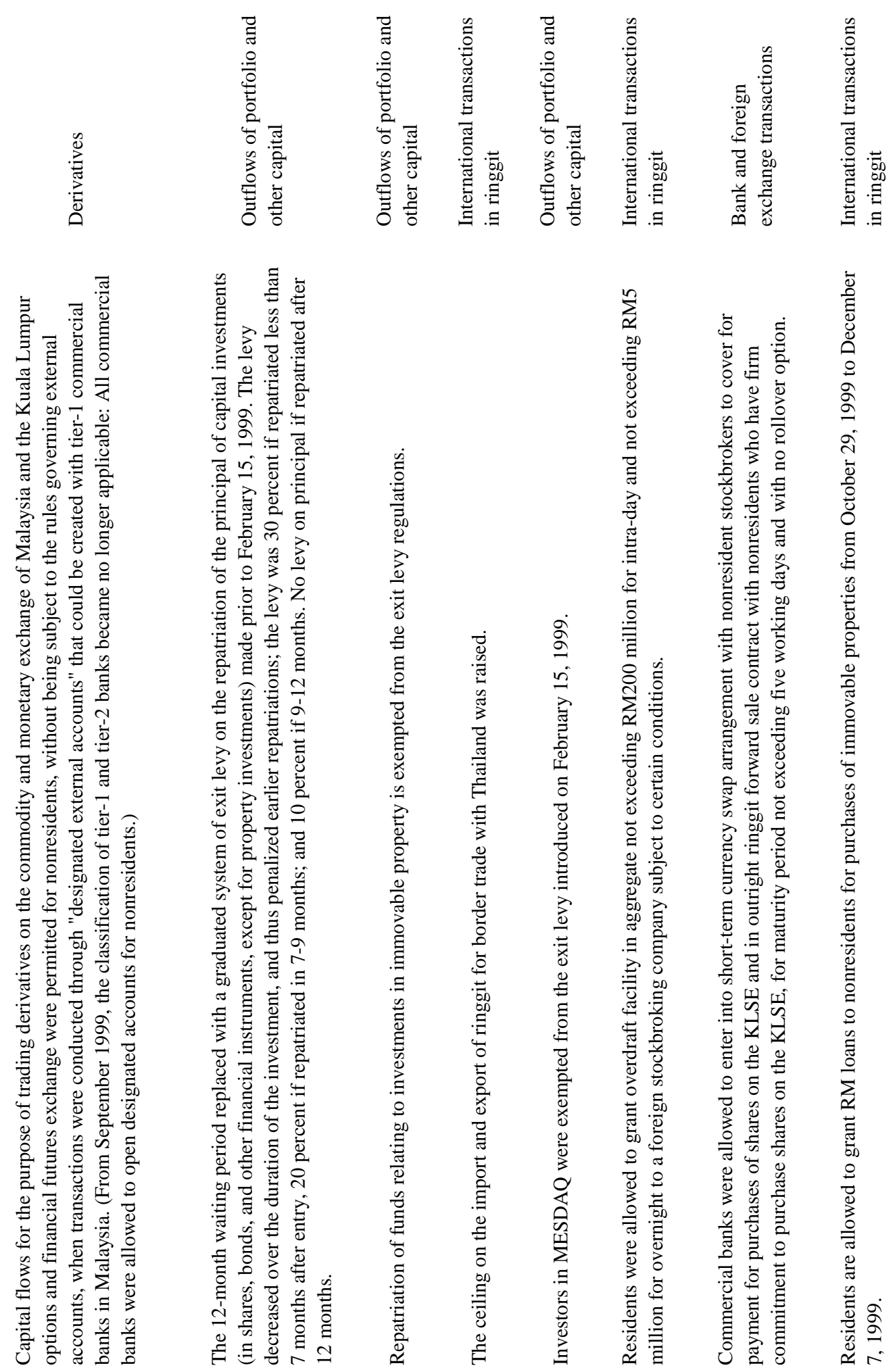

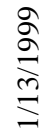

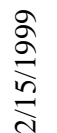

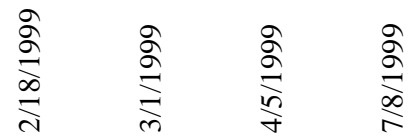

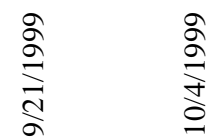



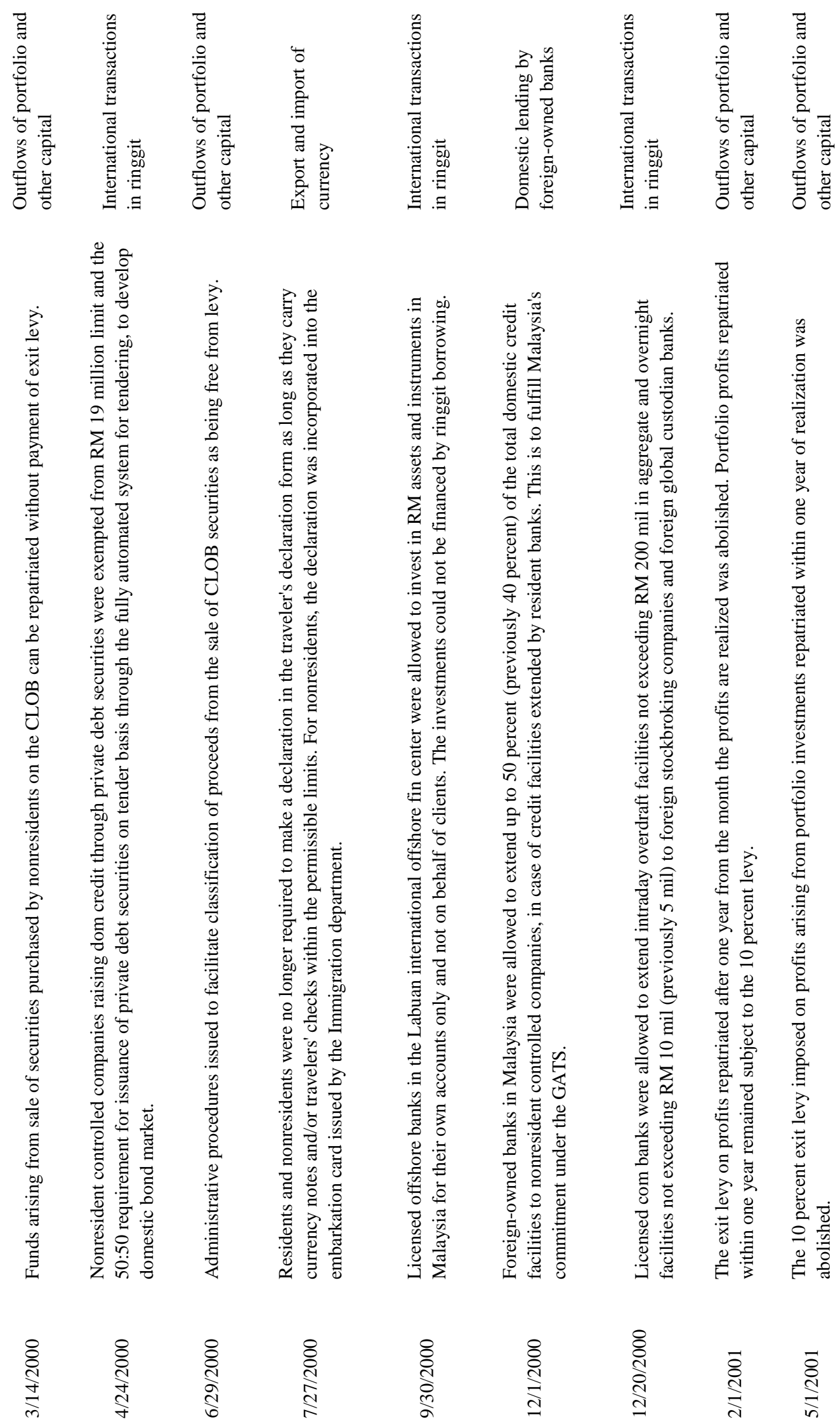

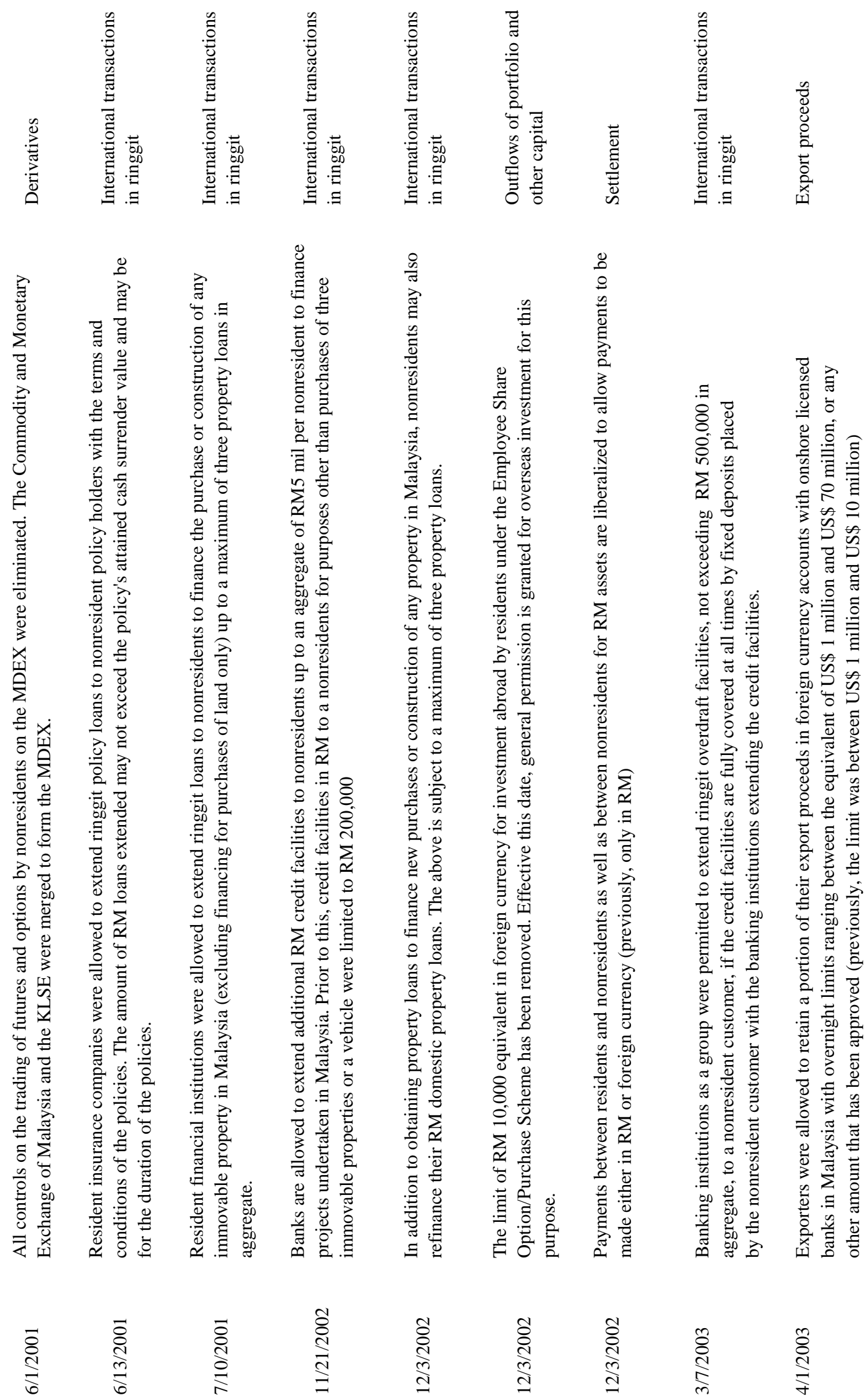

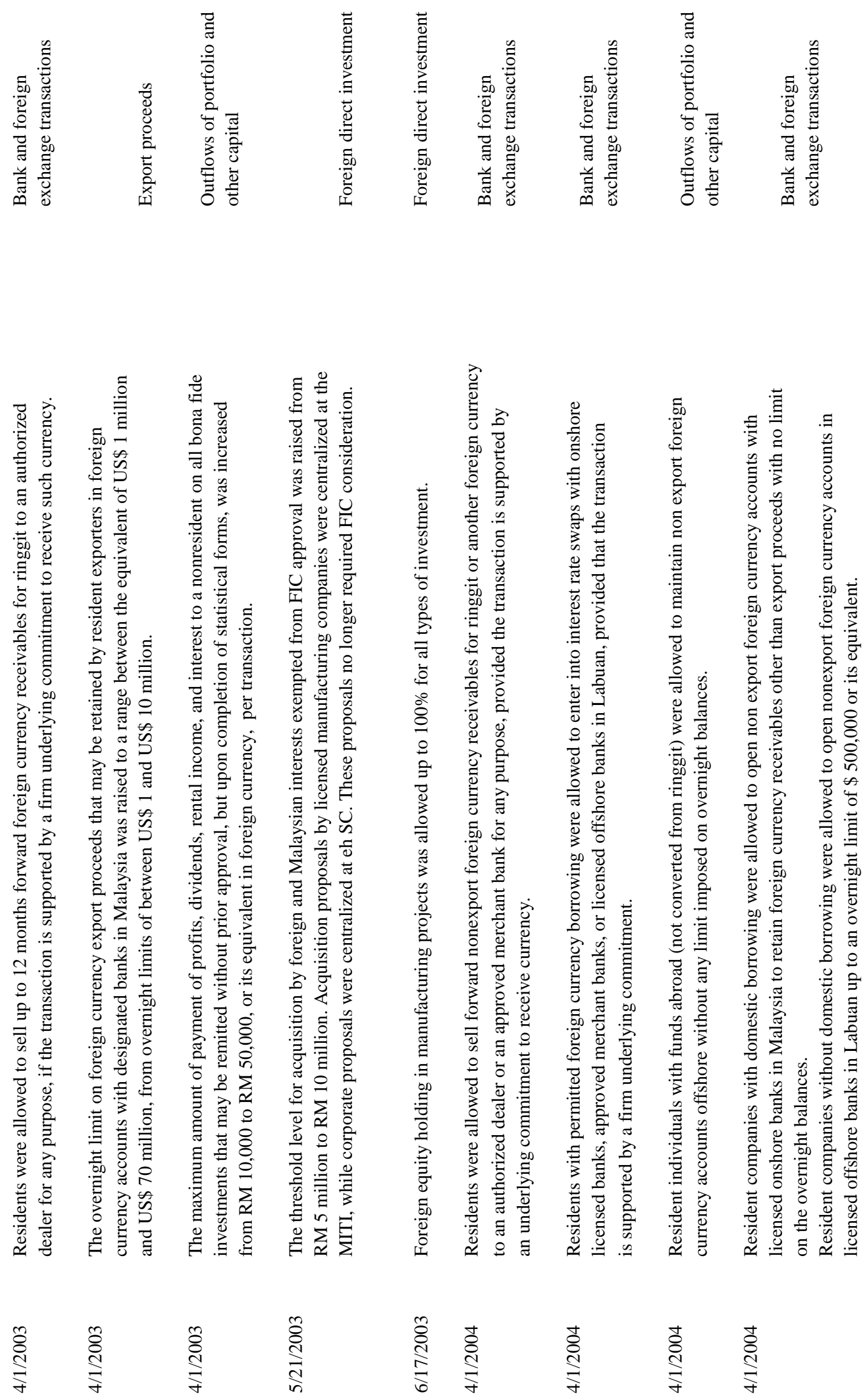

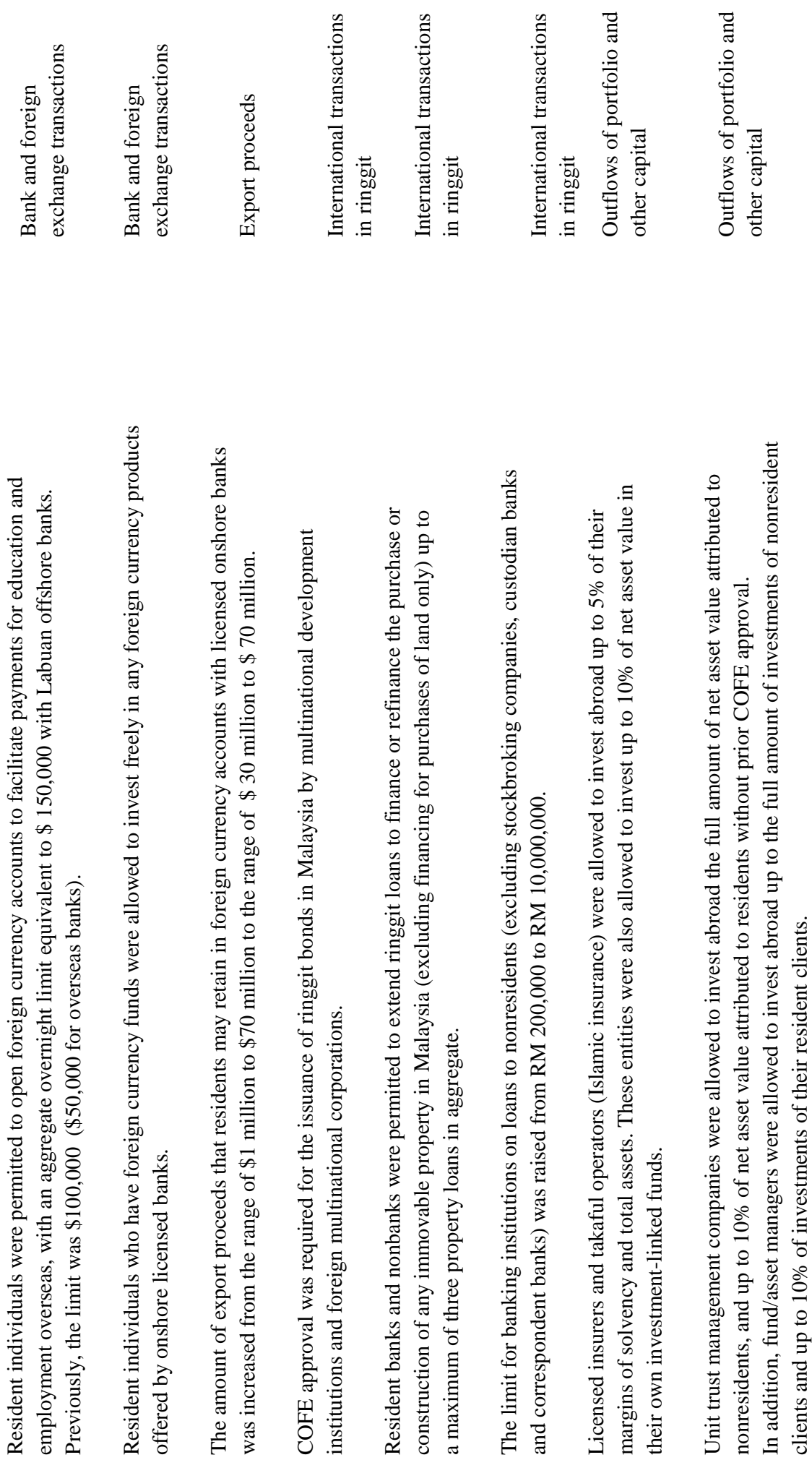

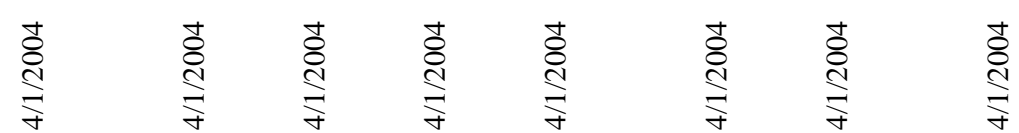



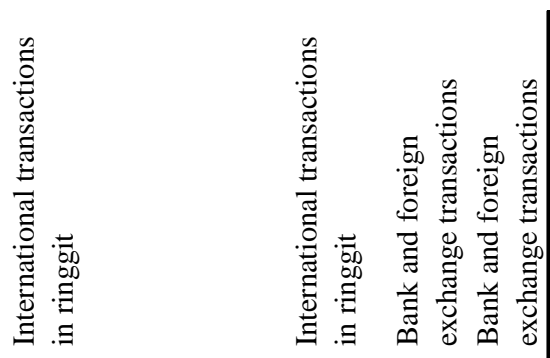

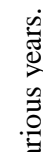

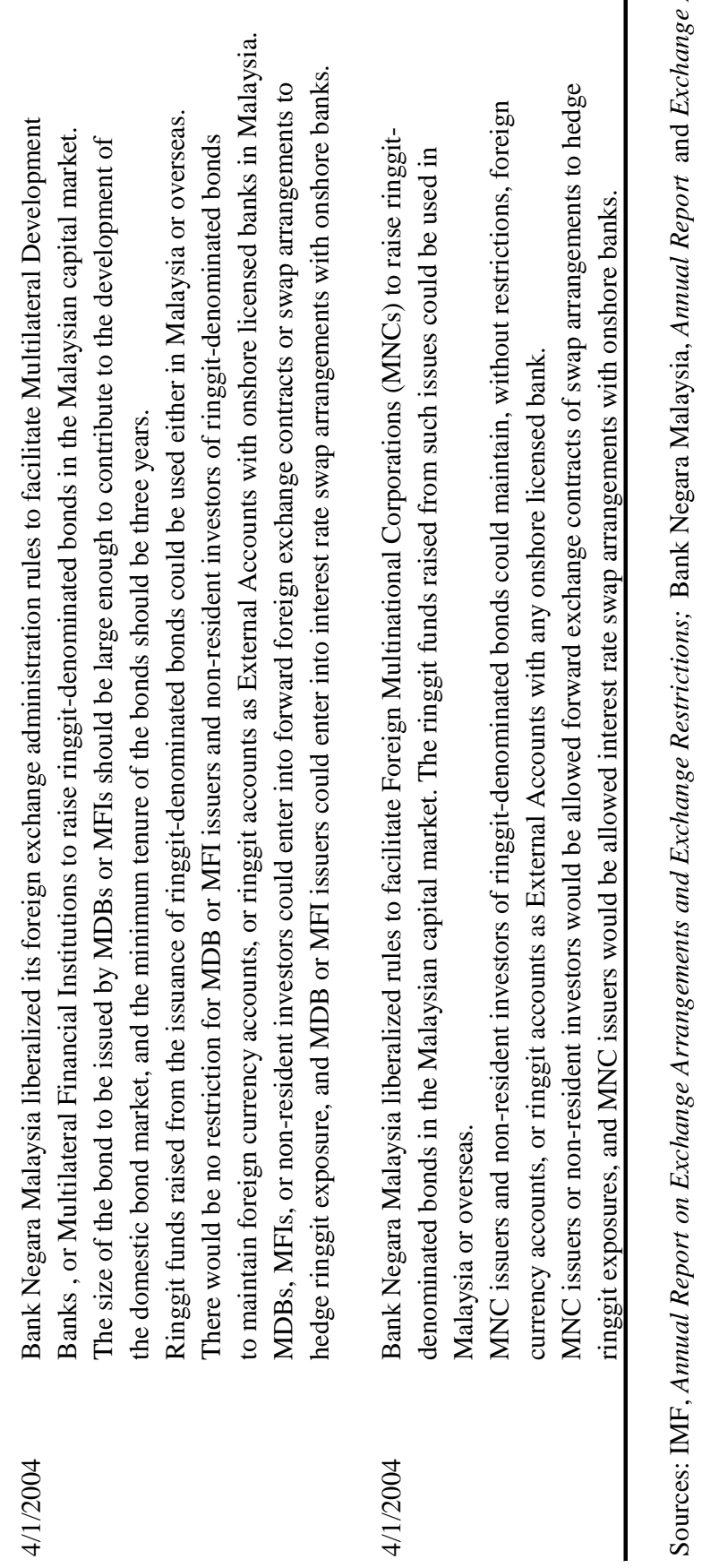




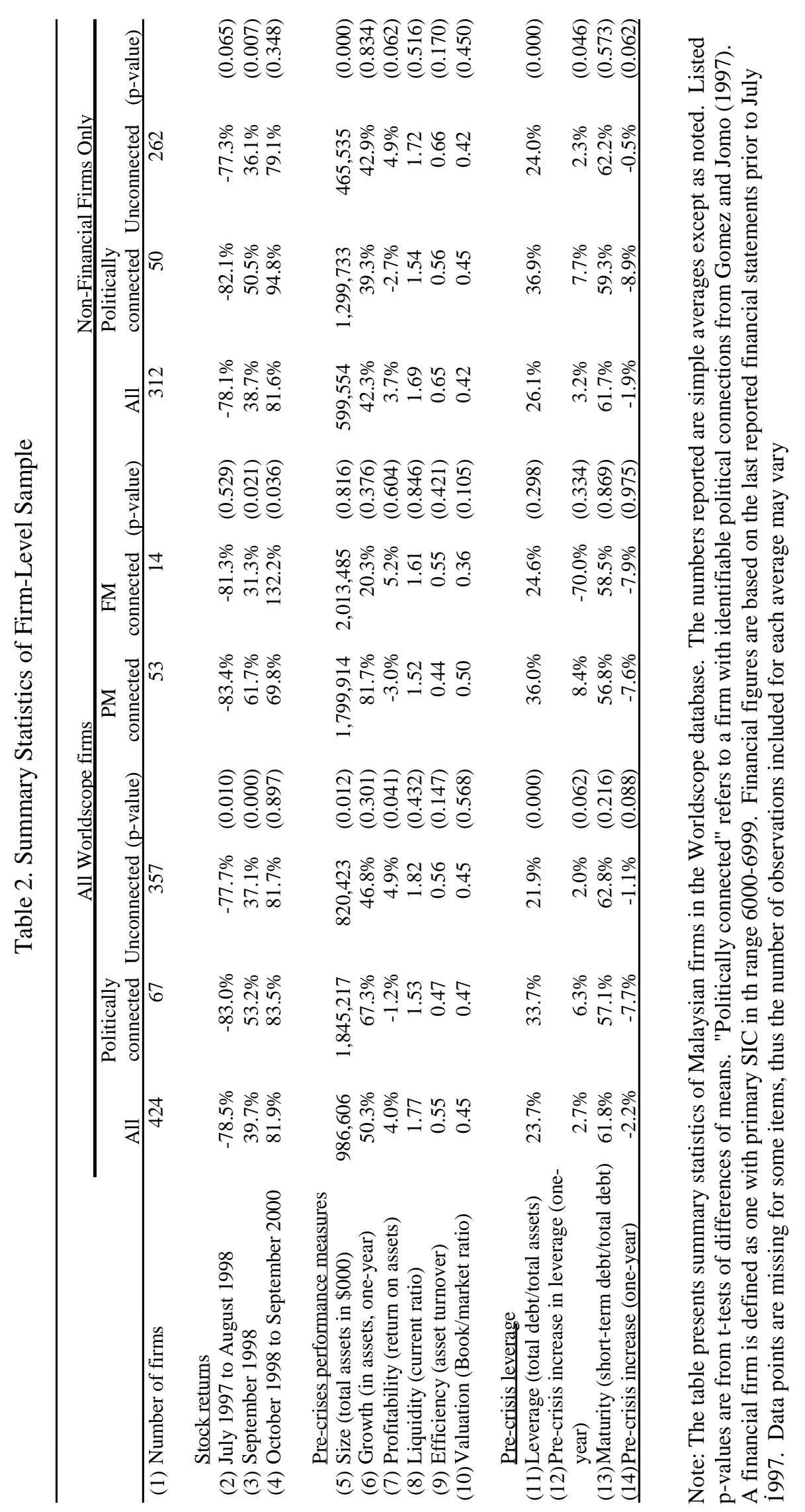




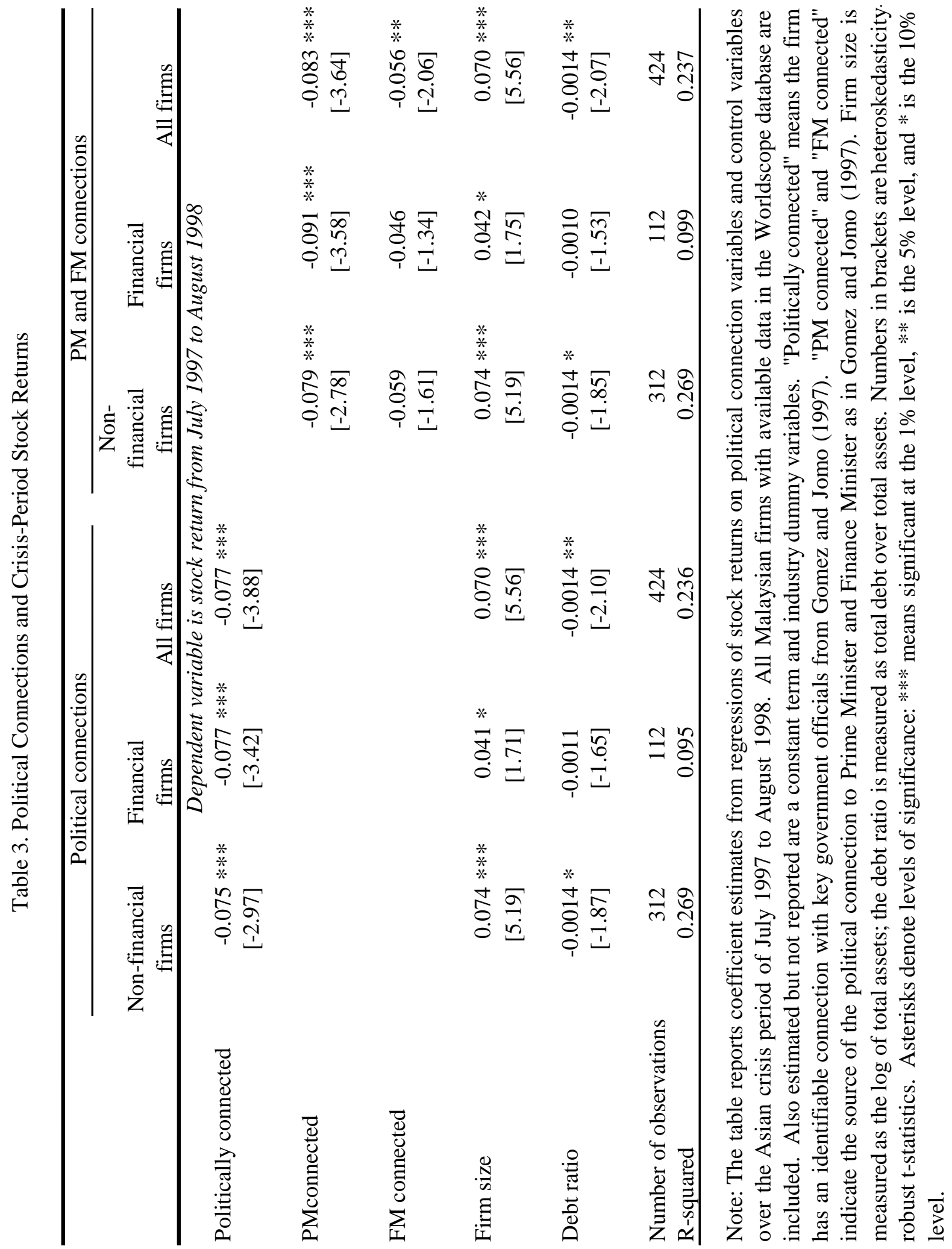




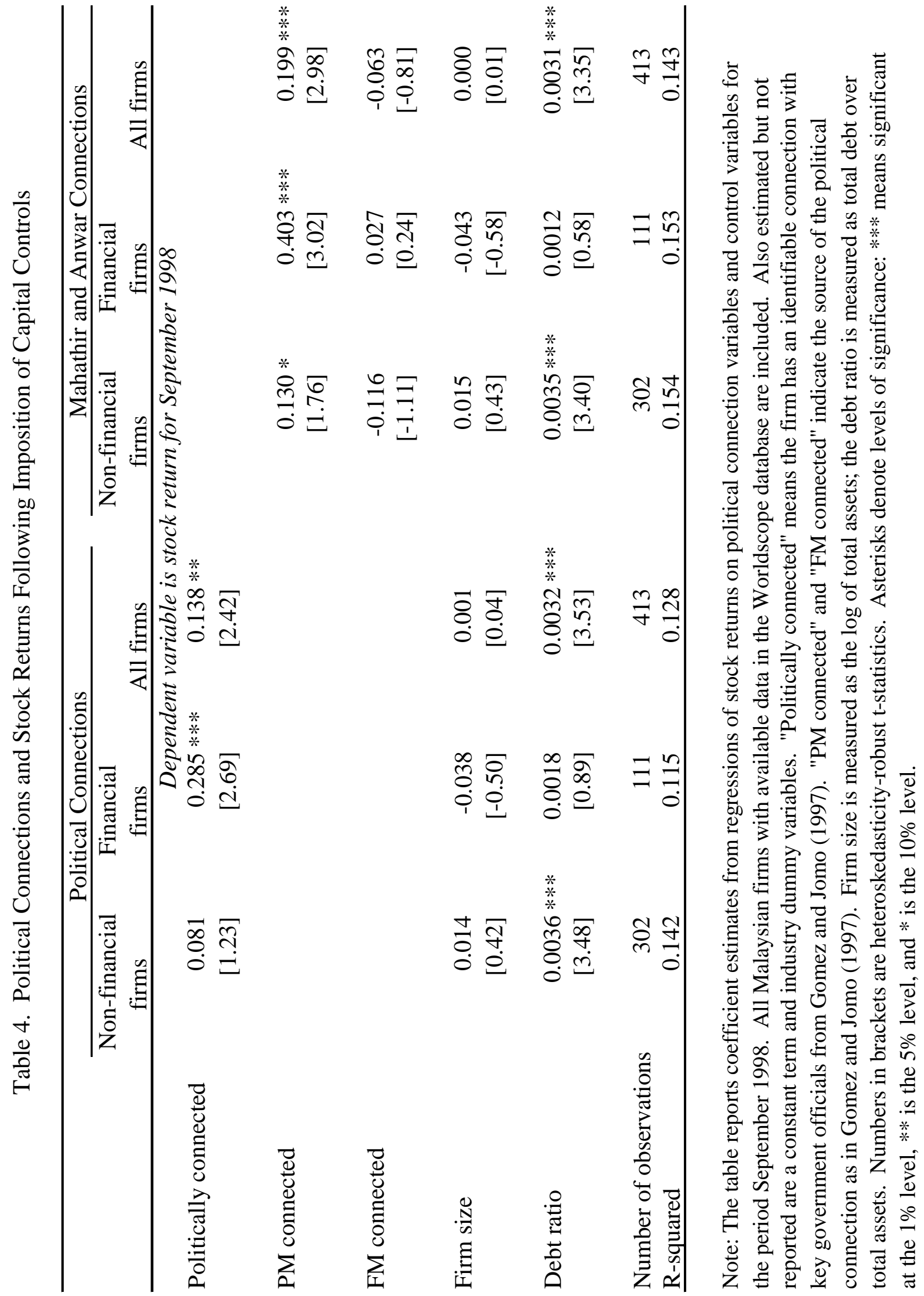




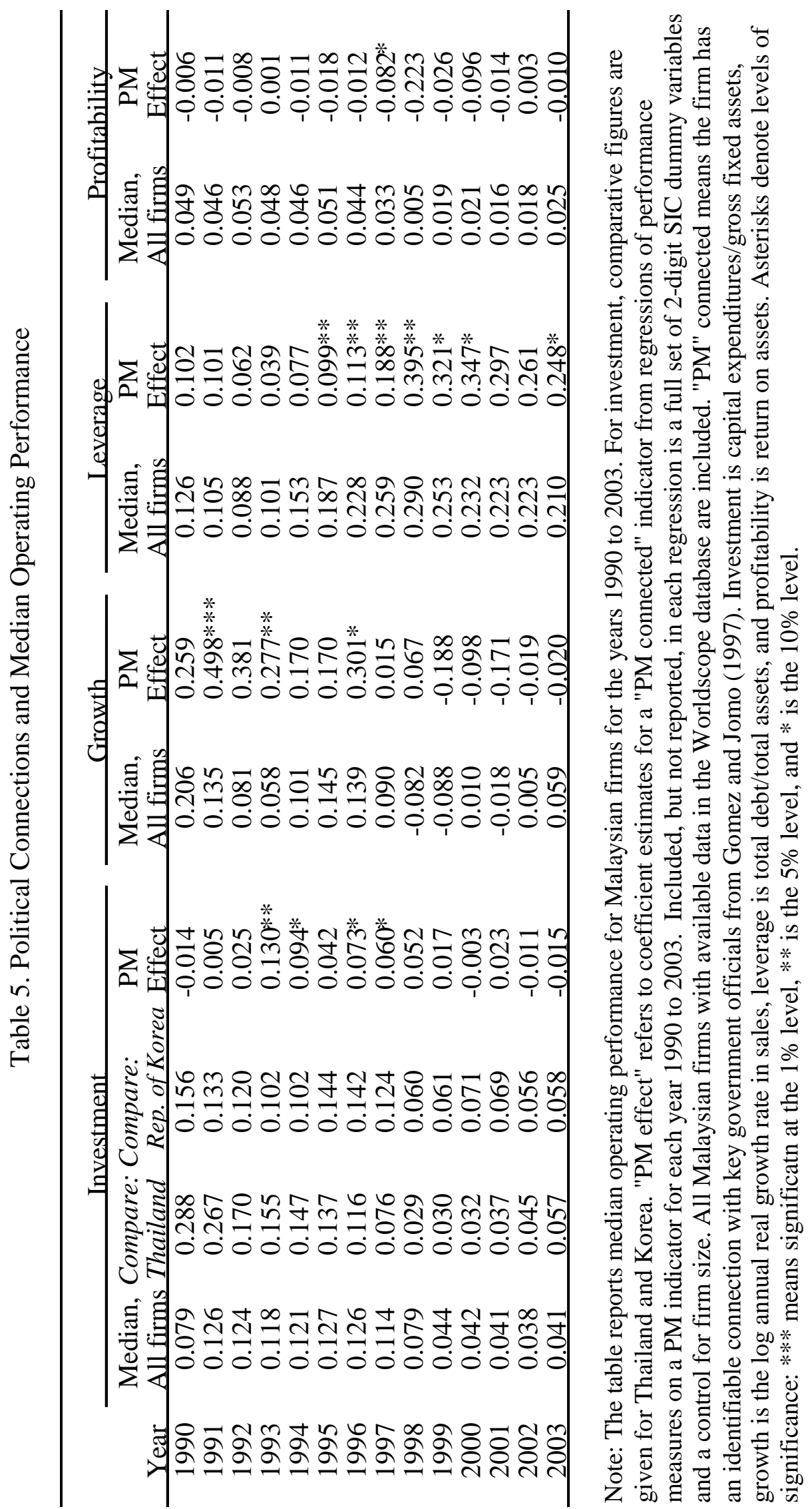




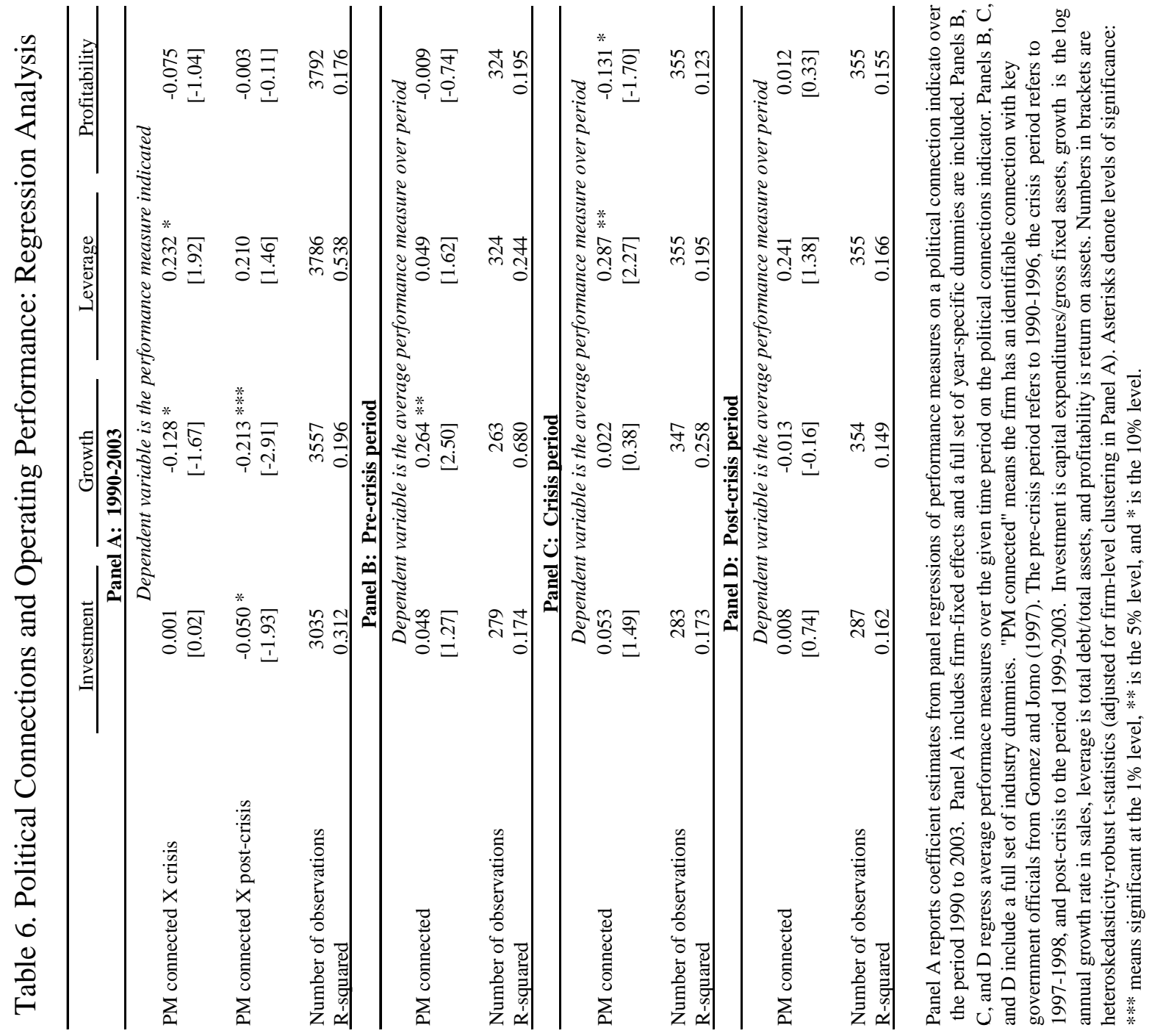




\section{REFERENCES}

Bhagwati, J., 1998a, “The Capital Myth,” Foreign Affairs, May/June, pp. 7-12.

, 1998b, "Why Free Capital Mobility May Be Hazardous to Your Health: Lessons from the Latest Financial Crisis?” paper presented at NBER Conference on Capital Controls, November 7.

Campbell, J., 1996, “Understanding Risk and Return,” Journal of Political Economy, Vol. 104, pp. 298-345.

Chong, B., M.-H. Liu, and K. Tan, 2005, “The Wealth Effect of Forced Bank Mergers and Cronyism,” Nanyang Technological University Working Paper.

Dhume, S., S. Crispin, S. Jayasankaran, and J. Larkin, 2001, “Economic Reform-Running Out of Steam,” Far Eastern Economic Review, January 18.

Dornbusch, R., 2001, “Malaysia: Was It Different?” NBER Working Paper No. 8325 (Cambridge, Massachusetts: National Bureau of Economic Research).

Faccio, M., 2006, “Politically Connected Firms,” American Economic Review, forthcoming.

Faccio, M., R. Masulis, and J. McConnell, 2006, “Political Connections and Corporate Bailouts,” Journal of Finance, forthcoming.

Fisman, R., 2001, "It's Not What You Know ... Estimating the Value of Political Connections,” American Economic Review, Vol. 91, pp. 1095-1102.

Gomez, E. T., and K.S. Jomo, 1997, Malaysia's Political Economy: Politics, Patronage and Profits, First Edition (Cambridge University Press).

, 1998, Malaysia's Political Economy: Politics, Patronage and Profit, Second Edition (Cambridge University Press).

Hutchison, M.M., 2001, "A Cure Worse than the Disease? Currency Crises and the Output Costs of IMF-Supported Stabilization Programs,” Economic Policy Research Unit, Institute of Economics, University of Copenhagen.

International Monetary Fund, 1999, “IMF Concludes Article IV Consultation with Malaysia,” IMF Public Information Notice No. 99/88, September 8, available on the Web at www.imf.org.

Jayasankaran, S., 1999a, “Saviour Complex,” Far Eastern Economic Review, August 12. , 1999b, “Merger by Decree,” Far Eastern Economic Review, September 9. 
, 2000, “Entrepreneurs-A Question of Honour: Renong Group Chairman Halim Saad wins a postponement of a purchase of shares he is committed to buy; the markets are appalled,” Far Eastern Economic Review, December 21.

Jeong, Se-Eun, and J. Mazier, 2003, “Equilibrium Exchange Rates of Eight East Asian Currencies: A Fundamental Equilibrium Exchange Rate (FEER) Approach,” CEPNUniversity of Paris-Nord Working Paper No. 09.

Johnson, S., and others, 2000, “Corporate Governance in the Asian Financial Crisis, 1997-98,” Journal of Financial Economics, Vol. 58, pp.141-86.

Johnson, S., and T. Mitton, 2003, “Cronyism and Capital Controls: Evidence from Malaysia,” Journal of Financial Economics, Vol. 67, No. 2, February, pp.351-82.

Jomo, K.S., 2001, Malaysian Eclipse: Economic Crisis and Recovery (London and New York: Zed Books).

Kaplan, E., and D. Rodrik, 2001, “Did the Malaysian Capital Controls Work?” NBER Working Paper No. 8142 (Cambridge, Massachusetts: National Bureau of Economic Research).

Krugman, P., 1998, “Saving Asia: It’s Time to Get Radical?” Fortune, September 7.

La Porta, R., and others, 1997, “Legal Determinants of External Finance,” Journal of Finance, Vol. 52, pp. 1131-50. , 1998, “Law and Finance,” Journal of Political Economy, Vol. 106, pp. 1115-55.

La Porta, R., F. Lopez-de-Silanes, and G. Zamarippa, 2003, “Related Lending,” Quarterly Journal of Economics, Vol. 118, pp. 231-68.

Latifah, M.C., 2002, “Capital Flows and Capital Controls: The Malaysian Experience,” in Globalization and the Asian Pacific Economy, ed. by Kyung Tae Lee (London and New York: Routledge).

Lemmon, M., K. Lins, 2003, “Ownership Structure, Corporate Governance, and Firm Value: Evidence from the East Asian Financial Crisis,” Journal of Finance, Vol. 58, pp. 1445-68.

Lindgren, C., and others, 1999, "Financial Sector Crisis and Restructuring: Lessons from Asia,” IMF Occasional Paper No. 188 (Washington: International Monetary Fund).

Lopez, L., 2001, “Mokhzani Mahathir exits two firms - Prime Minister’s son says he wants to put to rest accusations of nepotism,” Asian Wall Street Journal, April 30. 
Mahathir, M., 2000, The Malaysian Currency Crisis: How and Why it Happened? (Kuala Lumpur: Pelanduk Publications).

Meesook, K., and others, 2001, Malaysia: From Crisis to Recovery, IMF Occasional Paper No. 207 (Washington: International Monetary Fund).

Mitton, T., 2002, “Across-Firm Analysis of the Impact of Corporate Governance on the East Asian Financial Crisis,” Journal of Financial Economics, Vol. 64, pp. 215-41.

Morck, R., B. Yeung, and W. Yu, 2000, “The Information Content of Stock Markets: Why Do Emerging Markets Have Synchronous Stock Price Movements?” Journal of Financial Economics, Vol. 58, pp. 215-60.

Myers, S., 1977, “The Determinants of Corporate Borrowing,” Journal of Financial Economics, Vol. 5, pp. 147-75.

Perkins, D. H., and W.T. Woo, 2000, Malaysia: Adjusting to Deep Integration with the World Economy," in The Asian Financial Crisis: Lessons for a Resilient Asia, ed. by W.T. Woo, J. Sachs, and K. Schwab (Cambridge, Massachusetts: MIT Press).

Petersen, M., and R. Rajan, 1995, “The Effect of Credit Market Competition on Lending Relationships,” Quarterly Journal of Economics, Vol. 110, pp. 407-43.

Prystay, C., 2000, "Malaysia Reverses Course in Privatization Program—Government Nationalizes Two Light-Rail Projects,” Asian Wall Street Journal, December 27.

Rajan, R., L. Zingales, 1998, “Which Capitalism? Lessons from the East Asian Crisis,” Journal of Applied Corporate Finance, Vol. 11, pp. 40-48.

, 2003, "The Great Reversals: the Politics of Financial Development in the $20^{\text {th }}$ Century,” Journal of Financial Economics, Vol. 69, pp. 5-50.

Restall, H., 2000a, “Malaysia’s National Car Hurts Malaysians,” Asian Wall Street Journal Weekly Edition, August 28-September 3. , 2000b, “Reading Malaysia’s Rorschach Test,” Asian Wall Street Journal Weekly Edition, December pp. 11-17.

Rodrik, D., 2000, "Exchange Rate Regimes and Institutional Arrangements in the Shadow of Capital Flows” (unpublished; Cambridge, Massachusetts: Harvard University Working Paper).

Samad, M. F. B. A., undated, "Performance of Politically-Affiliated Businesses in Malaysia: A Summary of Principal Findings” (unpublished; Kuala Lumpur: University of Malaya Working Paper). 
Tamirisa, N. 2001, “Capital Controls in Response to the Asian Crisis,” in Malaysia: From Crisis to Recovery, ed. by Kanitta Meesook and others, IMF Occasional Paper No. 207 (Washington: International Monetary Fund).

, 2004, “Do Macroeconomic Effects of Capital Controls Vary by Their Type? Evidence from Malaysia, IMF Working Paper 04/03 (Washington: International Monetary Fund).

Titman, S., and R. Wessels, 1988, "The Determinants of Capital Structure Choice,” Journal of Finance, Vol. 43, pp. 1-19.

World Bank, 2000, "Malaysia: Social and Structural Review Update,” available on the Web at http://siteresources.worldbank.org/INTMALAYSIA/Resources/malaysia_STR_ update.pdf. 